\title{
POOLING AGREEMENTS IN CANADIAN OIL AND GAS LAW
}

\section{NIGEL BANKES ${ }^{*}$}

A pooling agreement is a private contractual response to a regulatory requirement. In this article, the author discusses the situations in which a pooling agreement is needed. The author also discusses the duties that may be owed by the owner of a working interest to the holders of nonparticipating interests when negotiating a pooling agreement.
Un accord de mise en commun est un contrat privé conclu en réponse à une exigence réglementaire. $L$ 'auteur du présent article examine les situations qui requièrent une telle mesure et quand une ordonnance de mise en commun peut être accordée. $L$ 'auteur parle également des obligations que le détenteur d'un intérêt économique direct a envers les détenteurs sans participation directe au moment de négocier un accord de mise en commun.

\section{TABLE OF CONTENTS}

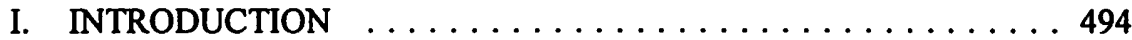

II. THE OBJECTIVES OF A POOLING AGREEMENT . . . . . 497

III. NEED FOR A POOLING AGREEMENT:

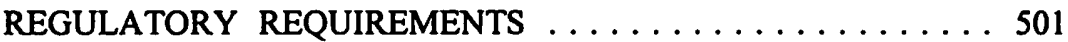

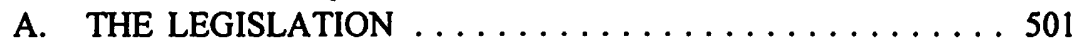

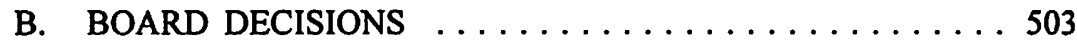

C. THE DOCTRINE OF EQUITABLE POOLING ....... 506

IV. NEED FOR A POOLING AGREEMENT:

LEASE REQUIREMENTS $\ldots \ldots \ldots \ldots \ldots \ldots \ldots \ldots \ldots 13$

A. THE POOLING CLAUSE IN

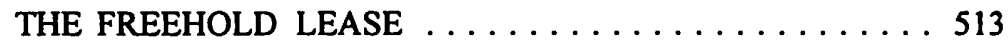

B. THE POOLING AGREEMENT AS PART

OF THE CHAIN OF TITLE $\ldots \ldots \ldots \ldots \ldots \ldots \ldots 14$

C. CERTAINTY, NOTICE AND

FORMALITY REQUIREMENTS . . . . . . . . . . . 519

V. POOLING AND NON-PARTICIPATING INTERESTS $\ldots \ldots \ldots 532$

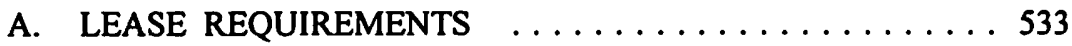

B. PRODUCTION ALLOCATION TO THE LESSOR

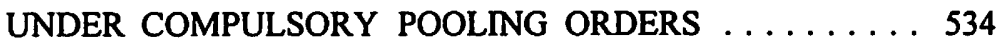

VI. OTHER NON-PARTICIPATING INTERESTS $\ldots \ldots \ldots \ldots \ldots 535$

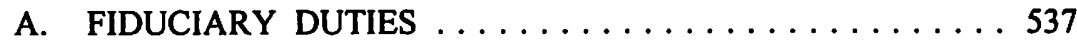

B. THE DUTY OF GOOD FAITH $\ldots \ldots \ldots \ldots \ldots \ldots \ldots 542$

VII. NON-PARTICIPATING INTERESTS - SUMMARY $\ldots \ldots \ldots 546$

VIII. LAND TITLES $\ldots \ldots \ldots \ldots \ldots \ldots \ldots \ldots \ldots \ldots \ldots \ldots \ldots \ldots \ldots$

IX. CONCLUSIONS $\ldots \ldots \ldots \ldots \ldots \ldots \ldots \ldots \ldots \ldots \ldots \ldots$

Associate Professor, Faculty of Law, University of Calgary. 


\section{INTRODUCTION}

This article has the modest aim of reviewing the law relating to pooling agreements in Canada. ${ }^{1}$ There is an extensive body of American literature on pooling, ${ }^{2}$ but little has been written on the subject in Canada. Most of the Canadian literature deals with the interpretation of the pooling clause in the lease or with the topic of compulsory pooling. ${ }^{3}$ The present article focuses on pooling agreements. As used here, the term pooling refers to an agreement or understanding pursuant to which the working interests for different contiguous tracts ${ }^{4}$ (geographical locations) are combined within the area of a drilling spacing unit ("DSU"). A DSU is the minimum area allocated by the relevant conservation authority for the purpose of drilling a well. I have used the term "agreement or understanding" to capture both enforceable contracts between arm's length parties as well as internal arrangements within a business entity, where that entity holds a working interest throughout the DSU but pursuant to more than one title document. I shall refer to such an arrangement as an "internal pooling."

A few other preliminary distinctions need to be made. First, the distinction between pooling agreements and unitization agreements. Pooling is distinguished from unitization primarily on the basis of the areal scope of the terms. Pooling is confined to the DSU, whereas unitization ${ }^{5}$ refers to combining property interests throughout a

The following individuals generously provided comments on an earlier draft of this article: David Blain, John Cuthbertson, Mitchell Shier and David Percy. I would like to thank them for their assistance. The remaining errors are of course my responsibility. I also acknowledge the assistance of Karine Fisher at the ERCB who provided me with access to a file dealing with compulsory pooling orders.

The main authorities are: R. Myers, The Law of Pooling and Unitization (Albany: Banks and Company, 1957) and B. Kramer \& R. Martin, The Law of Pooling and Unitization, 3d ed. (New York: Matthew Bender, 1994).

See W.H. Angus, "Voluntary Pooling in Canadian Oil and Gas Law" (1961) I Alta. L. Rev. 481; J. Ballem, The Oil and Gas Lease in Canada, $2 \mathrm{~d}$ ed. (Toronto: University of Toronto Press, 1985) at 170-78; and C.T. Mullane \& A.P.G. Walker, "The Pooling Clause and the Effects of Unitization on the Oil and Gas Lease" (1965) 4 Alta. L. Rev. 250. There is a short section in Bennett Jones Verchere \& N. Bankes, Canadian Oil and Gas, 2d ed. (Toronto: Butterworths, 1994) at paras. 7.99-7.103 dealing with the topic. Compulsory pooling is dealt with in the commentary to the Energy Resources Conservation Board in Canada Energy Law Service: Alberta (Toronto: Richard deBoo, 1994) at paras. 161-75. See also C.D. Hunt \& A.R. Lucas, Oil and Gas Law in Canada (Calgary: Carswell, 1990); the authors deal with compulsory pooling at 202-04 but not with pooling agreements.

A tract is an area inside a DSU within which an owner has the right to drill for and produce oil and gas: Oil and Gas Conservation Act, R.S.A. 1980, c. O-5, s. 70(b). It follows that a DSU may be composed of a single tract or multiple tracts.

Unitization or more specifically "unit operation" is defined in the Oil and Gas Conservation Act, ibid., s. 70(e) as follows:

"unit operation" means the operation in accordance with a scheme or plan for combining the interests of owners in a common source of supply of oil or gas in any field, pool or part thereof so that

(i) the operation may be conducted as if there were only one operator and one tract, and

(ii) the cost or expenses of the operation and the oil or gas produced by it are distributed among the owners or tracts according to a formula or a schedule of participation;

There are other differences between pooling and unitization. For example: (1) unitization ordinarily requires the consent of the holders of the corporeal interest, pooling ordinarily does not; 
pool. Although sometimes used interchangeably, a distinction between the terms is generally observed in leasing practices, ${ }^{6}$ statutory usage, ${ }^{7}$ the usage of the conservation

(2) historically, allocation within a pooled area would ordinarily be on the basis of surface areal contribution (see discussion infra at notes 143ff.), whereas unitization agreements always allocate on the basis of a tract participation factor; (3) in a unitization, the creation of a tract participation factor in the entire unit is invariably a matter of contract and not a matter of property. This follows from clause 306 of the Model Oil and Gas Unit Agreement adopted by the Petroleum and Natural Gas Committee at the 29th Mines Ministers Conference, Edmonton, September 1972: "Nothing herein shall be construed as a transfer or exchange of any interest in the Lease, Tracts or Unitized Zone, or in the Unitized Substances before production thereof." By contrast, a pooling agreement may, depending upon the language used, create a cross-conveyance (see infra accompanying text to notes 114-129).

The typical oil and gas lease generally provides that a lessee may pool the land but only so that the lands so pooled shall not exceed one spacing unit. See e.g. the CAPL 88 Alberta form of Petroleum and Natural Gas Lease at para. 9 [emphasis added]:

a) The Lessee is hereby given the right and power at any time and from time to time during and after the primary term to pool the said lands, or any portion thereof, or any zone or formation underlying the said lands or any portion thereof, or any of the leased substances therein, with any other lands or any zone or formation underlying such other lands or any portion thereof, or any of the leased substances therein, but so that the other lands or any zone or formation thereof, together with the said lands or any zone or formation thereof, shall not exceed one spacing unit. The Lessee shall thereafter give written notice to the Lessor describing the extent to which the said lands are being pooled and describing the spacing unit with respect to which they are so pooled. In the event of pooling there shall be allocated to that portion of the said lands included in the spacing unit that proportion of the total production of the leased substances from the spacing unit, after deducting any leased substances used in operations on the pooled lands, which the surface area of that portion of the said lands placed in the spacing unit bears to the total surface area of the lands in the spacing unit. The production so allocated shall be considered for all purposes, including the payment of royalty, to be the entire production of the leased substances from the portion of the said lands included in the pooling in the same manner as though produced from the said lands under the terms of the Lease.

b) The Lessee may terminate any pooling pursuant to subclause (a) of this clause and thereafter shall give written notice to the Lessor.

c) If the spacing unit pooled under this clause is varied or terminated by any statute, regulation, order of directive of any government or government agency, or if the pooling is terminated or invalidated by reason of the termination or expiration of a lease covering any lands, other than the said lands, within the spacing unit, or any other cause beyond the Lessee's reasonable control, and this Lease would otherwise terminate as a result of such variation or termination of the spacing unit or such termination or invalidation of the pooling, this Lease shall nonetheless continue in force for a period of 90 days after the Lessee received notice that the spacing unit has been varied or terminated or the pooling has been terminated or invalidated and the term of the Lease may be extended further pursuant to other provisions of this Lease, including without limitation the commencement of operations, within the said 90-day period.

d) The Lessee is hereby given the right and power at any time and from time to time during and after the primary term to include the said lands or any portion thereof or any zone or formation underlying the said lands or any portion thereof, or any of the leased substances therein, in a Unit Agreement for the unitized development or operation thereof with any other lands, or any zone or formation underlying such other lands, or any of the leased substances therein, if such becomes necessary or desirable in the opinion of the Lessee. The Lessee shall thereafter give written notice to the Lessor stating that the said lands are being or have been unitized. The basis and manner of any 
authorities ${ }^{8}$ and the literature. ${ }^{9}$ Secondly, pooling agreements should be distinguished from production allocation agreements. Production Allocation Agreements ("PAA") are designed "to promote economic production ... by the avoidance of unnecessary drilling." ${ }^{10}$ They are negotiated in situations where the working interest owners within different DSUs acknowledge that the resource can be economically exploited without needing to drill every DSU. A PAA is therefore designed, as the name suggests, to allocate production between the different tracts within the area covered by the agreement for the purposes of working interest holders and the owners of royalty interests. A PAA is something of a half-way house between pooling and unitization. It covers a larger area than does a pooling agreement but does not extend to the entire pool. Both unitization and PAAs are often accompanied by requests to the relevant conservation authority to relax conservation requirements ${ }^{11}$ such as off-target penalties.

such unitization, the manner of allocating unitized production among the several tracts of unitized lands, and the contents of any such Unit Agreement shall be in the sole discretion and determination of the Lessee, exercised bona fide, and when so determined shall be binding upon the Lessor.

e) In the event of unitization the production of leased substances which are unitized shall be allocated to that portion of the said lands included in the unit in accordance with the terms of the Unit Agreement. The production so allocated shall be considered for all purposes, including the payment of royalty, to be the entire production of the leased substances from the portion of the said lands included in the unit in the same manner as though produced from the said lands under the terms of this Lease. Upon notice from the Lessor, the Lessee shall provide the Lessor with a copy of the Unit Agreement within a reasonable time after the right and power granted hereunder has been exercised. The Lessee shall also have the right and power to withdraw the said lands, or any portion or portions of the said lands or the leased substances, from the Unit Agreement and shall give the Lessor written notice thereof.

f) Any operations conducted on the pooled lands or the unitized lands, whether conducted before, after or during the exercise of the right and powers granted under this clause, or the presence of a shut-in or suspended well on the pooled lands or the unitized lands, shall have the same effect in continuing this Lease in force and effect during the term hereby granted or any renewal or extension thereof as if such operations were upon the said lands, or as if said shut-in or suspended well were located on the said lands.

See also the pooling clause in the PanCanadian Lease form reproduced infra note 74.

Supra note 4, ss.72-82.

- See D.H. Breen, Alberta's Petroleum Industry and the Conservation Board (Edmonton: University of Alberta Press, 1993).

See e.g. Mullane \& Walker, supra note 3 at 250.

This quotation is taken from the preamble to the standard form production allocation agreements entered into on behalf of the Crown. These agreements are gazetted as a matter of standard practice. See e.g. the Forsyth Colony Agreement \#90001, A. Gaz. 1991.1.267.

Oil and Gas Conservation Act, supra note 4, s. 71(4) provides that when a pool or part of a pool is subject to a unit agreement, or within a block or a holding, the Board "may order that any provision of this Act or the regulations regarding the development and production of the oil or gas resources be varied or suspended in the pool or part of the pool." At the time of writing, the relevant Board was the Energy Resources Conservation Board (ERCB). However, with the proclamation of the Alberta Energy and Utilities Board Act, S.A. 1994, c. A-19.5, (Alberta Gazette, 1995, Part I, at 582), the relevant Board became the AEUB which assumed the responsibilities of both the ERCB and the Public Utilities Board. However, for the sake of simplicity and ease of revision, the article continues to refer to the ERCB. There were no substantive changes to the relevant legislation as part of this transfer of responsibilities. 
In the case of PAAs, this may result in the establishment of "blocks"12 or "holdings." 13 Production allocation agreements and blocks may give rise to a similar range of problems ${ }^{14}$ as occur in the case of pooling agreements. The focus of this article, however is limited to pooling agreements.

\section{THE OBJECTIVES OF A POOLING AGREEMENT}

The primary objective of pooling, whether by agreement or compulsory order, is to comply with the well (drilling) spacing requirements of modern oil and gas conservation legislation. It is therefore a private contractual response to a regulatory requirement.

The objectives of spacing legislation have been canvassed by others ${ }^{15}$ but, put briefly, such legislation limits the density of wells or the distance between wells. Although the rules have changed over time, ${ }^{16}$ and although conservation boards frequently grant exceptions, ${ }^{17}$ prevailing rules establish a DSU of one quarter section for oil wells and one section for gas wells. ${ }^{18}$ Spacing requirements are designed to modify some of the inevitable consequences of applying the rule of capture to oil and gas resources. ${ }^{19}$ In the absence of an areal allocation to each well, rational operators

12 A block consisting of contiguous DSUs in common ownership with a well capable of production, may be established for an oil pool with the approval of the Board; see Oil and Gas Conservation Regulations Alta. Reg. $151 / 71$ as. am., s. 5.100 [hereinafter OGCR].

A "holding" is to be composed of either a single DSU or whole contiguous DSUs of common ownership (ibid., s. 5.200).

A case in point is Vandergrift v. Coseka Resources Ltd. (1989), 67 Alta. L.R. (2d) 17 (Q.B.) [hereinafter Vandergrift]. The lands in which $\mathrm{V}$ had a royalty interest were included within a production allocation agreement and block. Two issues arose: (1) what duty was owed to the royalty holders by the working interest owner in entering into the agreement, and (2) whether the block order determined the production on which the royalty was to be calculated.

See Breen, supra note 8, especially at xlvi, 160; R. Harrison, "Regulation of Well Spacing in Oil and Gas Production" (1970) 8 Alta. L. Rev. 357.

Harrison, ibid.

17 The reasons for relaxing spacing requirements include situations in which the target formation has high viscosity and reserves could otherwise not be produced; see Canada Energy Law Service, supra note 3 at paras. 131-39 for discussion. On at least one occasion the Board granted a reduced spacing unit order instead of forcing the applicant to go through a forced pooling application, in a situation where a very small gas pool was discovered underlying a portion of one quarter section. See ERCB Decision D 87-5 (GNE Resources Ltd.). The Board took the view that pooling would be "an unnecessarily complicated and impractical approach to obtaining production."

Supra note 12, s. 4.020. The DSU is prescribed for a particular pool, geological formation or zone, not for the surface area, ibid., s. 4.010. For a case illustrating the difficulties that may arise where an operator wishes to explore different formations with different DSUs, see Canada Cities Service Petroleum Corp. v. Kininmonth (1964), 47 W.W.R. 437 (S.C.C.). The Alberta Conservation Board (now the ERCB) will licence a well that is to be drilled for gas production if the applicant has the rights to the oil well spacing unit on which the well is located. However, prior to placing the well on production, the licensee will have to certify that it has the right to produce from the entire gas well DSU; ERCB Informational Letter No. IL-OG 75-14.

Under the rule of capture, B, as "owner" of the mineral estate, is not able to restrain by injunction (or by a threat of damages action) a neighbour who is draining oil or gas from underneath B's property. The application of the rule, developed in the context of groundwater (although now modified in that context; see Re National Capital Commission and Pugliese (1978), 79 D.L.R. (3d) 
will continue to drill more and more wells ${ }^{20}$ until the marginal costs of drilling an extra well equal the anticipated returns. This results in over-investment ${ }^{21}$ and a decrease in reserves actually recovered. ${ }^{22}$

As a consequence of spacing requirements, the lessee of, say, the northwest quarter section will normally be unable to drill and produce from a gas well on its lands unless it can claim under an agreement with $B, C$ and $D$, the lessees respectively of the northeast, southwest and southeast quarter sections. In Alberta (and similarly in other jurisdictions $\mathrm{s}^{23}$ ) this requirement is enforced through the well licencing provisions of the Oil and Gas Conservation Act. ${ }^{24}$ Section 11 of the Act states that no well may be drilled without a licence and s. 12(3) provides that, ordinarily, only one well may be drilled in each DSU for each pool. Furthermore, s. 13 indicates that a person may only apply for a licence if "he is entitled, or is the authorized representative of the person who is entitled, to the right to produce the oil, gas or crude bitumen for the recovery or evaluation of which the well is to be drilled." The precise language is important and I shall consider these statutory provisions in more detail below.

Compliance with conservation legislation may be the main objective of a pooling agreement, but a pooling agreement also serves other purposes. The terms of the agreement will typically also deal with who is to operate the pooled lands, and how the costs of operations and the fruits of production are to be shared. The details of how the operations are actually to be carried out are ordinarily dealt with by appending an

592 (Ont. C.A.), aff'd on diff. grounds (1980), 97 D.L.R. (3d) 631 (S.C.C.)) to oil and gas resources rests upon the authority of Borys v. C.P.R., [1953] A.C. 217 (P.C.). In fact, Borys does not deal with the situation of neighbouring properties, but with the competing interests of the owners of the petroleum and of the gas-cap gas. Neither does Borys deal with a situation in which the gas is being saved and processed rather than flared. Although grounds therefore remain for questioning the application of Borys, in other fact situations its authority has recently been confirmed by the Alberta Court of Appeal in Prism Petroleum Ltd. v. Omega Hydrocarbons Ltd. (1994), 18 Alta. L.R. (3d) 225. But see Lickatz v. Magna Petroleums Lid, [1994] A.J. No. 819 (QL), McClung J.A. [hereinafter Foralla Resources], an unreported decision of the Alberta Court of Appeal, November 1, 1994, in which the Court suggested that an unjust enrichment remedy might lie where drainage was occurring within the DSU as a result of production from a well on one tract within the DSU but for which no pooling agreement existed to allocate production. The decision is dealt with in greater depth below. See accompanying text to infra note 53ff. See Breen, supra note 8 at xlii, citing an example from Texas, of 27 wells in a single acre. I.e., the investment of more capital than is required to do the job.

There is a well-established inverse correlation between the rate of recovery and ultimately recoverable reserves. While there may be no necessary connection between spacing and rate of recovery, the historical record shows that pressure will always be asserted on a regulator to permit a rate of recovery sufficient to allow timely recovery of invested capital; see Breen, supra note 8, especially his discussion of the history of the Turner Valley field, at 3-105.

For Manitoba, see Petroleum Drilling and Production Regulation, Man. Reg. 430/87 R, s. 11(4). The point is less clear in Saskatchewan; see The Oil and Gas Conservation Act, R.S.S. 1978, c. 0-2, s. 8 and The Oil and Gas Conservation Regulations, R.R.S. c. O-2, Reg. 1 Sask. Gaz. 1985.II.118, ss. 10, 15(3).

Supra note 4. See also supra note 18, discussing the practice of the ERCB to licence a well for drilling (but not for production) based upon ownership of the rights within an oil well DSU. 
operating agreement (such as the CAPL Operating Procedure) ${ }^{25}$ to the pooling agreement. On occasion, the parties in a DSU may agree to enter into a "pooling and farmout" agreement with one of the parties acting as the farmee, thereby bearing the sole risk of the operation and earning, in return, an interest in each of the other tracts in the DSU. ${ }^{26}$

Other commentators have suggested different objectives for pooling agreements. For example, in a Canadian context, Angus has suggested that pooling agreements are designed to save an operator from needless drilling pursuant to offset well obligations where the operator owns contiguous lease tracts. ${ }^{27}$ In the United States, pooling agreements seem to have been adopted as a response to judicial decisions declining to apportion royalties in a situation where property was divided after the lease was granted and the producing well was located on one of the tracts. ${ }^{28}$ The latter is purely an historical explanation for the development of the pooling agreement because issues such as these are now dealt with in the United States by apportionment clauses contained within the lease. ${ }^{29}$

In summary therefore, one can say that pooling agreements constitute a private law response to the spacing requirements of conservation legislation. However, in addition to meeting the minimum requirements of that legislation they will typically serve other functions such as the allocation of expenses, risk and production.

These introductory remarks have, no doubt, served to emphasize what the reader might have gleaned from the title, namely that what follows is primarily directed at practicing oil and gas lawyers. However, it is possible to locate this discussion within the broader public policy debate concerned with public and private law responses to the problems posed by limited access common property resources. ${ }^{30}$ That debate

25 The various iterations of the operating procedure of the Canadian Association of Petroleum Landmen ("CAPL") constitute the standard form operating procedure in use in western Canada. It is primarily designed for use by co-owners (i.e. tenants in common) of the same property and its use in both farmout and pooling situations may entail some awkwardness (see e.g. Article XXVIII, Term and Article XV, Relationship of Parties). CAPL has recently (January 1993) developed an operating procedure to be used during the earning phase of a farmout (during which time the farmee typically does not have a working interest) in recognition of some of these difficulties in the farmout context.

See e.g. Gas Initiatives Venture Lid. v. Beck, [1979] 3 W.W.R. 741, 100 D.L.R. (3d) 291 (Alta. S.C.T.D.) [hereinafter Gas Initiatives], rev'd with the consent of the applicants and without written reasons (1981), 122 D.L.R. (3d) 768 (Alta. C.A.).

27 Supra note 3 at $481-82$. This usage of the term pooling will generally fall outside the usage adopted in this article. The pooling agreements envisaged by Angus relate to more than a single DSU.

28 See Kramer \& Martin, supra note 2 at para. 7.01; Mullane \& Walker, supra note 3 at 251 . Under Canadian law, royalties would ordinarily be apportioned on a pro rata basis by reference to the surface area. See Re Dawson and Bell, [1945] O.R. 825 (C.A.); and see discussion in Ballem, supra note 3 at $145-46$. Ibid.

30 A "limited access" common property resource is a resource to which access is controlled either by the physical properties of the resource itself (e.g. an oil or gas reservoir or pool) or by law or other customary norms. A limited access resource should be contrasted with an open access resource 
emphasizes that common property resources such as oil and gas, water resources and the fishery are prone to all the evils of resource degradation, rent dissipation and the like. ${ }^{31}$ The literature on the topic, from Hardin's famous "Tragedy of the Commons ${ }^{132}$ to the many works dealing with the "prisoner's dilemma" problems posed by common property resources, ${ }^{33}$ suggests that there is a certain inevitability (the classical sense of the word tragedy ${ }^{34}$ ) about the degradation of these resources. In recent years that view has been contested by authors such as Elinor Ostrom in her book, Governing the Commons. ${ }^{35}$ Ostrom's thesis is that while it may be true to say that in many cases common property resources end up being degraded, there is no inevitability or immutable law that requires this. Indeed, there are many situations in which resource users have been able to escape the dilemmas of their situation. These examples of success, argues Ostrom, should be closely analyzed for the lessons that they may teach us about the management of common property resources. Ostrom's work is concerned exclusively ${ }^{36}$ with renewable resources, but one of her observations seems particularly pertinent in the present context. Ostrom observes that some of the most successful strategies for dealing with common property problems rely on mixed public and private solutions rather than the leviathan solution of state control, or complete privatization. I think that the example of pooling tends to support this observation. Private pooling agreements are, along with unitization and the applicable provisions of the oil and gas conservation legislation dealing with spacing requirements and compulsory pooling, part of the complex of public and private responses to the problems posed by the common property nature of the oil and gas resource. There can be little doubt, certainly in contrast with other common property resources, that this mixed public and private approach has been successful. ${ }^{37}$

This presentation of the objectives of the pooling agreement and the broader context of common property resources has served to introduce the subject. The next two parts deal with the need for a pooling agreement, emphasizing both the requirements of

For a general discussion, see E. Ostrom, Governing the Commons: The Evolution of Institutions for Collective Action (Cambridge: Cambridge University Press, 1990) [hereinafter Governing the Commons].

32 G. Hardin, "The Tragedy of the Commons" (1968) 162 Science 1243, reproduced in L. Jaffe \& L. Tribe, Environmental Protection (Chicago: The Bracton Press, 1971) at 23-34.

33 Although these games seem highly artificial, the general principle and hard lesson to be drawn from prisoner's dilemma games is that, under certain conditions, individually rational strategies will lead to collectively irrational outcomes: Ostrom, supra note 31 at 5 . See also D. Parfit, Reasons and Persons (Oxford: Oxford University Press, 1984), especially at c. 2 of Part One, and for an application in the context of the atmosphere, see P. Danielson, "Personal Responsibility" in H. Coward \& T. Hurka, eds., Ethics and Climate Change: The Greenhouse Effect (Waterloo: Wilfrid Laurier University Press, 1993) at 81-98.

34 See C. Rose, "The Comedy of the Commons: Custom, Commerce, and Inherently Public Property" (1986) 53 U. Chic. L. Rev. 711 and "Given-ness and Gift: Property and the Quest for Environmental Ethics" (1994) 24 Env. L. 1. Supra note 31 .

Ibid. at 26.

At least one influential commentator has suggested that the approach of pooling development rights might be adapted to deal with a range of environmental ills. See E. Freyfogle, "Ownership and Ecology" (1993) 43 Case W. Res. L. Rev. 1269 at 1296. 
conservation legislation and of the relevant title documents (leases). Consideration is given to a number of questions, including: who is a necessary party; and formality, notice and certainty requirements. Thereafter, the article addresses the duties that might be owed by the owner of a working interest to the holders of non-participating interests when negotiating a pooling agreement. The final part of the article briefly addresses some land titles questions associated with pooling agreements. The article concludes with suggestions for statutory reform.

\section{NEED FOR A POOLING AGREEMENT: REGULATORY REQUIREMENTS}

If the pooling agreement is primarily designed to meet the requirements of the spacing legislation, it follows that we should begin our inquiry with an investigation of when an agreement is required and who the necessary parties are.

\section{A. THE LEGISLATION}

It is obvious that a pooling agreement is required if the working interests in the different tracts that make up the DSU are owned by different parties. Thus if A, B, C and $\mathrm{D}$ each hold, individually, a 100 percent undivided interest in one lease for a quarter section of land which together make up a whole section, they must combine together in some way to support an application for a licence to the relevant conservation authority. Section 13 of the Oil and Gas Conservation Act ${ }^{38}$ of Alberta is typical of the requirements imposed by conservation statutes:

No person shall apply for a licence

(a) for a well for the recovery of oil or gas from a drilling spacing unit,

unless he is entitled, or is the authorized representative of the person who is entitled, to the right to produce the oil [or] gas ... for the recovery or evaluation of which the well is to be drilled.

In most instances, it is the existence of a pooling agreement that will allow the applicant (A) to claim that it is the authorized representative of the persons (A, B, C and D) "entitled ... to the right to produce." But what if we change the facts slightly? What if we assume (example 2) that $A$ has, in addition to its 100 percent interest in the northwest quarter, a 10 percent undivided interest in each of the leases to the other quarter sections? In the new situation, A has an undivided interest throughout the DSU, although its percentage interest varies. Does $A$ require a pooling agreement or some other form of authorization to apply for a licence or is A entitled to apply independently of $B, C$ and $D$ ?

The answer to this question must turn upon the proper construction of s. 13 of the $A c t$, although it should be borne in mind that even if A has the right to apply for a licence, the Energy Resources Conservation Board ("ERCB") may decline to grant the 
licence, for the Board undoubtedly has this discretion under s. 14 of the Act. $^{39}$ Nevertheless, we may still inquire as to the policy reasons that may lie behind such a decision.

The first step in construing s. 13 is to ask who "is entitled ... to the right to produce"? The use of the term "entitled" indicates that the answer is to be found not within the Oil and Gas Conservation Act, but within the general law of property and the instruments of title on which the applicant relies. General property law principles suggest that a tenant in common (such as A in example 2) is entitled to the use and occupation of the joint property and cannot be restrained from exploring and exploiting the property under the doctrine of waste. ${ }^{40}$ Although there are some American states that take a contrary view, the majority view, and the view taken by Canadian commentators who have considered the issue, ${ }^{41}$ is that it is not waste to produce, using reasonable methods consistent with good oilfield practice, the oil and gas or minerals that are jointly owned. There is, however, a duty to account to the other co-owners for their proportionate share. There is no reason to think that this common law position has been changed in Alberta by the amendments to Part III of the Law of Property Act dealing with partition and sale. ${ }^{42}$

This line of reasoning would lead us to the tentative conclusion that $A$, in example 2 , would be entitled to apply for a licence without the concurrence of $B, C$ and $D$ and ought to be granted a licence unless there are good policy reasons dictating otherwise. Possible reasons might include equity considerations as between the tract owners. Equity issues might arise because of the limitations on the duty to account. The duty to account exists as between co-owners for production from the particular tract that is held in common. The law of co-ownership tells us nothing about the duties of co-

Section 14 reads as follows:

14(1) On receiving an application for a licence, the Board may grant the licence subject to any conditions, restrictions and stipulations that may be set out in or attached to the licence or it may refuse the licence.

(2) When the Board has refused a licence, the Lieutenant Governor in Council, in his discretion, may review the application and may direct the Board to issue the licence.

(3) The Board shall keep a record of licences granted. See Job v. Potton (1875), 20 L.R. Eq. 84; Hersey v. Murphy (1920), 48 N.B.R. 65 (Ch. Div.). See J.J. Park, "Marketing Production from Joint Property: The Past, The Present and The Future" (1990) 28 Alta. L. Rev. 34 at 35-36; R.C. Muir, "Split Sales of Gas" (1971) 9 Alta. L. Rev. 496 at 498 .

R.S.A. 1980, c. L-8, s. 17, see in particular ss. $17(2)$ (c) \& (d). In my view, the amendments to the Act in 1979 (S.A. 1979, c. 59) were intended to codify the common law rules. The amendments were based upon the report of the Institute for Law Research and Reform, Partition and Sale, Report No. 23, 1977. The Report noted at 34 (and see also at 30) that:

Although the law relating to accounting between co-owners regulates that relationship both during and at termination of co-ownership, this report is concerned only with accounting at the latter stage. However, as we believe that the rules which have been developed are generally satisfactory, our basic recommendation is that a court, when making an order under the proposed Act, continued to be empowered to provide for an accounting according to the existing rules of law and equity. To assist the parties and the courts, we think that the proposed Act should restate the basic elements of those rules, with such clarification as seems necessary." [emphasis added]. 
owners vis-à-vis each other. Before reaching a final conclusion on this point I shall canvass the relevant decisions of the ERCB.

\section{B. BOARD DECISIONS}

The language of the Oil and Gas Conservation Act has been considered in several decisions of the ERCB. ${ }^{43}$ The issue first arose, quite indirectly, in a 1971 decision of the Board on an application for a compulsory pooling order in the Leduc-Woodbend area. ${ }^{44}$ Spruce Oils had obtained leases for a total of a 96 percent undivided interest in the southwest quarter. It was apparently unable to secure a lease for the remaining 4 percent interest, and therefore sought to have the Board make a compulsory pooling order.

The Board rejected the application on two grounds. First, the Board was of the view that Spruce Oils had not brought itself within the ambit of the Act, since the owner of the 4 percent undivided interest in the corporeal estate was not the owner of a tract within the meaning of the Act. The Act defined "tract," in s. 70(b), as "an area within a drilling spacing unit or pool ... within which an owner has the right or an interest in the right to drill for or produce oil or gas." The Board was clearly of the view that a compulsory pooling order was only available against the owner of another tract and not against another person who held another undivided interest in the same tract. The reason for this interpretation is provided by the Board's second ground for rejecting the application, and is most germane to the present discussion: "Spruce Oils Ltd., as lessee of an undivided fractional interest in all of the oil and gas rights within the drilling spacing unit, would, on a suitable application, be granted a well license, and therefore, the order applied for is not necessary 'to permit the drilling for or production of oil or gas from the drilling spacing unit.'" In my view, the Board's conclusion on this second ground was correct, based upon the above understanding of the rights of a tenant in common. It would not have mattered whether Spruce had held a 4 percent or a 96 percent interest. Unfortunately, the Board did not provide anything further in the way of supporting reasoning and, in particular, did not indicate what it might have meant by the phrase "a suitable application." This issue was effectively raised by the 1990 application, of Blue Range Resources, for an amended well licence. ${ }^{45}$

In addition to the two decisions discussed in the text, see also ERCB Decision D 90-2 re: Victor R. Durish and Seascape Oil and Gas Ltd. That decision concerned an application for the transfer of a well licence from Seascape to Durish. A well had been drilled on the northwest quarter and at the time of the application Durish owned the mineral estate in the entirety of the north half. Both Durish and Seascape claimed leasehold interests in the south half. Seascape was the current licensee and had obtained a transfer of the licence at a time when there was an ongoing dispute as to the property between Durish and Seascape's predecessor in title. The Board noted that: (a) Seascape could not produce the well for gas since it had no pooling agreement in place, but that (b) as the well was located on Durish's land, Durish could produce oil from the well and could test the well for gas production without the need for any agreement with other mineral owners in the section. Consequently, the Board rescinded the transfer of the well licence to Seascape and granted Durish's request for a transfer of the licence.

44 ERCB Decision D 71-16 [hereinafter Spruce Oils] [emphasis added].

45 ERCB Decision D 90-12. 
Blue Range was the operator of a well on the southeast quarter of section 29. It sought an amendment to its licence to permit oil production from the Viking formation on quarter section spacing, and for gas production from the Glauconitic on one section spacing. The application was only contentious in relation to the Glauconitic. The gas rights in section 29 were divided into three tracts: the north half, the southeast quarter and the southwest quarter. Blue Range had an undivided interest in the gas rights in each of the tracts. The application was opposed by Mission Resources, which held an undivided interest in the mineral rights for the south half of the section. The Board, which had added the Board Solicitor, Michael Bruni, to the panel for the hearing, rejected the application. Before considering the Board's reasons it will be helpful to again reproduce s. 13 of the Oil and Gas Conservation Act:

No person shall apply for a licence

(a) for a well for the recovery of oil or gas from a drilling spacing unit,

unless he is entitled, or is the authorized representative of the person who is entitled, to the right to produce the oil [or] gas ... for the recovery or evaluation of which the well is to be drilled.

Mission contested the application on the basis that Blue Range was not a person entitled to produce within the meaning of s. 13 of the $A c t$, since s. 13 anticipated an agreement amongst all the parties having an interest in the minerals. It further argued that Blue Range was neither a person entitled to produce, nor the authorized representative of such a person. The Board unequivocally rejected both arguments, ruling that Blue Range was entitled to make the application by virtue of its undivided interest in the Glauconitic formation. This conclusion accords with my analysis above.

The Board went on to say that, had the section been composed of a single tract, each party holding an undivided interest "would have equal status in approaching the Board for a well licence. Since the DSU would be only one tract, no pooling would be necessary." The Board referred to its Spruce Oils decision in support of this conclusion and the clear implication (though not expressed) is that the Board would have granted the application had there been a single tract for the DSU. That, however, was not this case:

In this case, the Board notes that the DSU is made up of three tracts with varying ownership. Therefore, the Board believes that the tracts must be pooled in some manner to form a complete DSU prior to a licence being granted for the production of Glauconitic gas. To this end the applicant has two alternatives, either to pool the tracts on a voluntary basis or to approach the Board for a compulsory pooling order under section 72 of the Act. [emphasis added]

The first part of the Board's decision accords with the argument being made above. A pooling agreement is not required to support a well licence application where the applicant has an undivided interest throughout the DSU, at least where the DSU 
consists of a single tract. ${ }^{46}$ The second part of the Board's decision is more problematic, primarily because the Board has provided no supporting reasons for its conclusion that pooling is required where the DSU is split into different tracts. However, I think that the conclusion is correct as a matter of policy and may be justified as a matter of law simply upon the basis that under s. 14 of the Act the Board may either grant the application subject to terms and conditions or "may refuse the licence." While it is undoubtedly the case that a refusal could not be based upon arbitrary or capricious grounds, the Board clearly has a broad discretion.

The primary reason for thinking that the decision is correct on policy grounds is simply that in the absence of a pooling agreement, a compulsory pooling order, or the adoption of some doctrine of equitable pooling in Alberta (discussed below), there would be no method of allocating production amongst the working interest owners ${ }^{47}$ of the tracts within the DSU. The common law of co-ownership would not provide a solution and in fact would dictate that production from the southeast quarter (where the well was drilled) should be divided in accordance with the ownership interests in that quarter section rather than on the basis of the entire section. Clearly this might lead to inequity and would conflict with the injunction contained in the statement of purposes of the Act (s. 4): "to afford each owner the opportunity of obtaining his share of the production of oil or gas from any pool."

Consequently, we may conclude that while a party may apply to the Board for a licence without the concurrence of other owners whenever it has an undivided interest throughout the DSU, ${ }^{48}$ as a matter of policy, a licence should only be granted in such a case if the ownership interests are identical throughout all the tracts making up the DSU. The difficulty with this conclusion, however, is that in the ordinary case, the Board may not be aware that ownership interests are not identical throughout the DSU. ${ }^{49}$

Although it may seem surprising that a licence should be granted to one working interest owner (however small her interest) if ownership interests throughout the DSU are the same, the conclusion does make good policy sense and is unlikely, as a matter of practice, to be abused. The protection against abuse lies in the fact that the up-front risk of drilling the exploratory well will be borne by those who elect to go ahead with an operation on the lands. A non-consenting co-owner has no obligation to contribute $^{50}$ and yet, at the same time, is entitled to receive its proportionate share of

The same reasoning would no doubt support the grant of a licence where the DSU was divided into tracts but where the titles to each tract were held in the same proportions.

An allocation amongst the owners of the corporeal estate for royalty purposes might be prescribed by the terms of the respective leases, but in most cases the existence of a pooling agreement would be a condition precedent to the sharing.

Of course, in most circumstances, operations on the lands will be conducted in accordance with terms of an operating agreement to which all the working interest owners are parties.

Certainly, the Board's well licence application form does not compel disclosure; see discussion in the accompanying text to infra note 213.

Ruptash and Lumsden v. Zawick, [1956] S.C.R. 347. 
production. ${ }^{51}$ The policy sense of the conclusion is simply that it encourages exploration that is consistent with conservation requirements, and yet at the same time denies a veto to the owner of a small undivided interest. ${ }^{52}$

\section{THE DOCTRINE OF EQUITABLE POOLING}

The predicate of the conclusion in the last section, to the effect that the Board would be fully justified on policy grounds in refusing to grant a well licence in a situation where ownership interests were not the same throughout the different tracts of a DSU, was that there would be no method of sharing production between tracts within the DSU. This has now been called into question by the recent decision of the Alberta Court of Appeal, affirming an unreported oral decision of Miller A.C.J. in Foralta Resources. ${ }^{53}$ Briefly, the facts involved a single section of land split into four tracts of a quarter section each. Each of the tracts had been leased or otherwise granted in the late 1940s. ${ }^{54}$ The grant of rights to the northwest quarter did not provide for the possibility of pooling for the purposes of gas production. Each of the properties ultimately became vested in a single working interest owner, Foralta. A gas well was drilled on the northwest quarter in the early 1980s and gas was ultimately produced. Foralta, no doubt planning an internal pooling, attempted to obtain the consent of the lessors to the inclusion within the lease of a clause that would have permitted pooling and the allocation of production on an acreage basis. All parties consented except the plaintiffs who held the mineral title to the northwest quarter where the well was located. Faced with this refusal, the defendants sought a compulsory pooling order from the ERCB but the application was denied. The Board's letter to the applicant stated: ${ }^{\text {ss }}$

See generally supra notes 40,41 .

There would be no way around the veto if the Board's decision in Spruce Oils, supra note 44 is correct and the Board's compulsory pooling jurisdiction is not available to solve the problem.

Supra note 19. I have digested the case in Canadian Oil and Gas, supra note 3.1 am grateful to David Rode for providing me with a copy of the trial judgment and the agreed statement of facts. The grant of rights to the northwest quarter in 1948 did not take the form of a conventional lease. Rather, it took the form of an agreement of sale by which the purchaser obtained an $871 / 2$ percent interest in the petroleum substances. The vendor retained legal title to the entire estate as well as the ownership of a $12 \mathrm{1} / 2$ percent interest in the petroleum substances and was thereby entitled to delivery of $121 / 2$ percent of production (cl. 14). The agreement did not provide for a specific term (i.e. duration) but indicated that the purchaser could continue in possession provided that it continued to fulfill all the conditions of the bargain including the drilling of one well per legal subdivision ("LSD") within the quarter section. The property produced oil for many years from deeper formations before the gas well that was the subject of the present controversy was drilled. The agreement is on file with the ERCB as part of Application \#9000241, which was the application for a compulsory pooling order discussed infra. Prior to production, Foralta applied to the Board for compulsory purchaser and processor orders. The parties to the dispute negotiated a production allocation agreement for three sections of land within the same pool but the terms of that agreement do not have a significant bearing on the issues in the case.

My attention was drawn to this point by item 33 of the Agreed Statement of Facts. The quotation is from the Board's letter of 29 March 1990 to J.K. Farries; Ms. Karine Fisher of the ERCB provided me with a copy. There are at least two distinct situations in which the Board can be persuaded to grant a pooling order. The first is that in which the applicant is unable to get a lease for every tract within the DSU. This may be because the property has been sub-divided and it is either impossible (because they cannot be traced) or prohibitively expensive (i.e. high transaction costs), to obtain leases from all the tract owners, or exceptionally, where a party owning a tract 
Based on the evidence submitted, the Board has concluded that compulsory pooling within the drilling spacing unit (DSU) comprising section 31 is not required. Therefore, the application for a compulsory pooling order is denied.

Section 72 of the Oil and Gas Conservation Act (the Act) provides for pooling of all tracts within the DSU in situations where the applicant is not able to obtain a lease for the mineral rights to all of the tracts within the DSU, and thus does not have the right to drill for or to produce oil or gas from the DSU. In this case the Board noted from Legal's [Foralta's predecessor in title] evidence that it has leases for all the tracts within the subject DSU, and therefore it already has the right to produce the well in question. Consequently, there is no need for the order as prescribed under section 72 of the Act.

The defendants initially failed to pay any royalties to the plaintiffs and subsequently only paid a royalty on 25 percent of production from the well. The defendants similarly paid the royalty reserved by each of the other leases in the section on 25 percent of production. The plaintiffs sued for an accounting, seeking an order that the royalty should be paid on the entirety of the production. The plaintiffs lost both at trial and before the Court of Appeal.

Miller A.C.J. gave three distinct grounds for rejecting the application at trial. First, he suggested that the establishment of DSUs by the 1952 amendments to the Oil and Gas Conservation Act superseded the provisions of the lease. Although the judgment is lacking in detail and does not refer to specific sections of the legislation, or the actual statutory language, the general thrust of the judgment is clear: since the legislation limited the number of wells that could be drilled within a DSU, it mattered not where the well was drilled; production should be shared on an acreage basis within the DSU. For good measure, Miller A.C.J. added that the relevant provisions were clearly intended to be retroactive.

is unwilling to grant a lease (see Paloma Petroleums, E86-10). This category of cases is ordinarily dealt with by Board examiners. For representative examples see Canadian Occidental, E87-12; Passburg Petroleums, E86-16; Geoscan Resources, E86-22. The second category of cases is usually initiated when all the tracts have been leased but the working interest owners are unable to agree upon an allocation of costs or production. This category of cases is frequently dealt with by a panel of the Board. The considerations relevant to these decisions are well dealt with in discussion in the Canada Energy Law Service, supra note 3. I have not discovered a decision of the Board in which it has granted an application where the applicant already had an undivided interest in the entire DSU and therefore the right to produce oil or gas from the DSU. Indeed, the Board's decision in Spruce Oils, supra note 44, suggests that such an application would not be considered. Hence, it is somewhat puzzling to note the remarks of Justice Miller at page 252 of the transcript of decision in Foralta Resources that counsel, an expert witness (Mr. J.K. Farries) and apparently the Court itself, considered that the Board's refusal to grant the application that had been brought in the instant case was unprecedented and indeed surprising. Even the one unusual aspect of the case, namely that (as noted, supra note 54) the "lessor" actually had an undivided $12 \frac{1}{2}$ percent interest in the minerals, instead of the usual royalty interest, would not have helped Foralta make its case insofar as Foralta could still claim to be entitled to drill and produce throughout the DSU on the basis of its $871 \%$ percent undivided interest in the northwest quarter and its leases to the other three quarter sections. 
The so-called "doctrine of equitable pooling" developed by the courts of some American states ${ }^{56}$ provided the second ground for rejecting the plaintiffs' claim. The principle of equitable pooling is discussed in Kramer and Martin's book, on The Law of Pooling and Unitization, as an interesting historical footnote. ${ }^{57}$ The doctrine allowed courts to deem that pooling had occurred within a spacing unit even though there was no agreement between the parties. The doctrine could be relied upon by the lessee of a tract in a number of situations: as against the owners of other tracts to compel sharing of production; by a royalty owner in order to compel the payment of a royalty on production from within the spacing unit but outside the lands to which the royalty applied; and, most importantly, by a lessee in order to extend the term of a lease beyond the primary term in a situation in which production was occurring within the DSU but not within the leased area. ${ }^{58}$ Kramer and Martin state that the doctrine was developed in those states that had adopted spacing requirements but had not yet adopted compulsory pooling legislation. In effect, it was a judicial response to what might otherwise have been viewed as an unconstitutional taking of property. Miller A.C.J. noted that although the doctrine had never before been applied in Canadian law, he would have no hesitation in applying it here and, in order to give it effect, he would apply the allocation proposed by Foralta which "is equitable as it is based upon the respective acreages."

Justice Miller was also able to reach the same conclusion by applying the doctrine of unjust enrichment. He reasoned that since the well on the northwest quarter was capturing reserves underlying the balance of the section, the plaintiffs would be unjustly enriched were they to receive a royalty based upon 100 percent of production. He also observed that it would be inequitable if Foralta had to pay a royalty to the plaintiffs on 100 percent of production and then a further royalty to the lessees of the other three quarter sections. To counter that possibility, the defendants (Foralta) had commenced what Miller A.C.J. referred to as a counterclaim, seeking an order that, if the plaintiffs were successful, the defendant should be entitled to recover from the lessors of the other three quarters monies which it had paid in the form of a royalty. Justice Miller found it unnecessary to consider the counterclaim. Instead, he tied the loose ends up with these observations:

To allow Lickatz to receive four times as much as the others would, in my view, amount to an unjust enrichment in their favour as they are all drawing the gas from the same pool.

In the end result then, if I rule that Legal [Foralta] owed Lickatz a full 12 and a half percent royalty on the production from IIA [the well on the northwest quarter], I would then in equity have to order that Lickatz should pay back to the other three their full share to counter the unjust enrichment, and this would end up with the same financial situation as that already proposed and followed by Legal [Foralta].

36 The doctrine was particularly well-developed in Mississippi and Louisiana.

57 Supra note 2 at para. 7.02 .

sh Ibid. at para 7.02, referring to Texas Gulf Producing Co. v. Griffith, 218 Miss. 109 (1953) 2 o. \& G. 1103. 
On appeal, the Court of Appeal dismissed both an appeal and a cross-appeal with the briefest of oral judgments. The Court affirmed that the 1952 amendments confined the plaintiffs to 25 percent of production from the DSU, or as the court put it, "the pooling unit." "Each owner," it said, "must share equally in the production." The Court also endorsed and adopted Justice Miller's conclusion on the issue of unjust enrichment, but found it unnecessary to deal with his observations on the doctrine of equitable pooling other than to observe that "we think that there is much force to the argument that the equitable doctrine has been overtaken by Alberta's regulatory scheme as expressed in the legislation."

While the conclusions of both courts seem, in some very general sense, to be "equitable," each of the three reasons articulated is subject to serious criticism, not least because neither judgment refers to any supporting or opposing case law and because the statutory references are at such an abstract and general level that one is forced to infer much of the reasoning that led to the conclusion.

Bound up in the claim that the 1952 amendments to the Oil and Gas Conservation Act retrospectively confined the plaintiffs to a royalty on 25 percent of production, must be the proposition that these amendments effected a unilateral change to the royalty clause of the lease. In order to achieve that effect, one would expect some very specific statutory language. As it happens, there were no statutory amendments to the Act in 1952 that even dealt with the issues of pooling or lease royalty clauses. ${ }^{59}$ All that happened in 1952 was an amendment to the Drilling and Production Regulations ${ }^{60}$ that changed the spacing unit for gas wells from forty acres to 640 acres. Regulations cannot themselves divest property rights ${ }^{61}$ and the judgment of the Court must therefore turn upon the language of the statute itself. This is not the place to reach a definitive conclusion on this debate, but one can suggest that the statutory and regulatory changes in 1952 did not, unlike the situation in Mercury Oils Ltd v. VulcanBrown Petroleums Ltd. $^{62}$ make it impossible for the lessee to fulfil its contractual

The only amendment to the $A C l$ in 1952 (S.A. 1952, c. 65) dealt with a series of housekeeping matters and entitled the Board to a lien in certain circumstances. As stated in supra note 54, there was no conventional royalty clause in the instrument by which Foralta obtained its rights, but the point is still the same, only stronger given the nature of the plaintiffs' reserved rights under the agreement of sale. O.C. 631, A. Gaz. 1950.1.822 as am. by 0.C. 946, A. Gaz. 1952.1.1021.

61 Spooner Oils Limited v. The Turner Valley Gas Conservation Board, [1933] S.C.R. 629 especially at $638 \mathrm{ff}$.

[1943] S.C.R. 37 [hereinafter Mercury Oils]. The defendant had agreed to drill two wells on the leased property. After the lease was executed the applicable regulations were changed to "ordinarily make it impossible to drill a second well on a 40 acre plot" An application for a licence to drill the second well was rejected. In the Supreme Court of Canada it was held that the obligation did not cause the defendant to lose its rights under the lease largely because if the well were drilled the defendant would breach a compliance with laws clause contained within the lease. The case was therefore resolved at the level of interpreting inconsistent provisions in the contract. The so-called "overriding" provisions of the Oil and Gas Conservation Act, now found in s. 9, were not in the $A c t$ at the time and do not appear to have been added until 1957 (S.A. 1957, c. 63). Of course, some of the obligations in the 1948 agreement of sale (see supra note 54), by which the defendants obtained their interests (e.g. the drilling of multiple wells) might well have been covered by the reasoning in Mercury Oils, but it does not follow therefore that the obligation 
obligations. ${ }^{63}$ They merely made it more expensive, or required that the lessee negotiate a pooling agreement or obtain a pooling order from the Board (if eligible). In any event, since the well was not drilled until the early 1980s, should the Court not have considered the relevant statutory provisions at that time, rather than those from $1952 ?$

There are at least two objections that can be made to the adoption of the equitable pooling doctrine in Alberta in 1994. The first objection is simply that if the doctrine were part of our law, one could reasonably have expected the courts to have declared that to be the case in earlier decisions dealing with pooling situations. As noted above, the fully developed American doctrine admits of the possibility that a lease within the DSU may be continued by production elsewhere within the DSU, without the need for a pooling agreement. This is surely inconsistent with the decisions of Canadian courts in the Gibbard, ${ }^{64}$ Gunderson, ${ }^{65}$ and Gas Initiatives ${ }^{66}$ cases, all of which are discussed in some detail below. The general tenor of those cases is clear. The courts will not intervene to save a party from a poorly drafted bargain, or more specifically, a poorly drafted pooling clause. The fact that the predecessors in title of the defendants had failed to include a pooling clause in the lease is unfortunate, but not something that permits the court to adjust the terms of the bargain.

The second objection is that the doctrine was developed in those states that did not have a set of compulsory pooling provisions in their conservation statutes. Such provisions were introduced into the Alberta $A c t$ in 1957 and were therefore certainly in force at the time that the well was drilled. These provisions may well not speak to the full range of circumstances in which the relevant parties are unable to agree upon a pooling arrangement, but they do suggest that the Legislature has considered the problem, and therefore that the range of judicial intervention is thereby correspondingly reduced. Finally, one could object to the doctrine on the grounds that judicial remedies of this sort lack the precision that can be obtained through the compulsory pooling provisions of conservation statutes. ${ }^{67}$ Such statutes may provide for the allocation of production on a basis other than an acreage basis, and may provide for the allocation of drilling costs, where appropriate, as well as penalties. While those matters may not have been an issue in the present case, they are surely issues that should be taken into account when a court is deciding whether or not to adopt the principle of judicially enforced "equitable" pooling.

As with the doctrine of equitable pooling, application of the principles of unjust enrichment to the Foralta Resources fact situation has considerable intuitive appeal. However, if one unpacks the various elements of the doctrine, it is clearly very difficult to apply to the facts of this litigation. I think that it can also be suggested that if one

to pay a $121 / 2$ percent share of production had also been amended.

See also Vandergrift, supra note 14 at 32.

Gibbard v. Shell Oil Company of Canada (1961), 36 W.W.R. 529 (S.C.C.) [hereinafter Gibbard].

Shell Oil v. Gunderson, [1960] S.C.R. 424 [hereinafter Gunderson].

Supra note 26.

This criticism is made in Kramer \& Martin, supra note 2 at 7-11, para. 7.02. 
accepts that unjust enrichment may be available to counter what is in effect a drainage situation, one has in fact mounted a full frontal assault (albeit unwittingly) on the rule of capture.

In order to succeed in a claim for unjust enrichment, the plaintiff must establish, at a minimum, an enrichment, a corresponding deprivation and the absence of a juristic reason for the enrichment. ${ }^{68}$ On one analysis, the receipt of 100 percent of the royalty by Lickatz is an enrichment, and its payment by the lessee a deprivation. But there is clearly a juristic reason for this in the form of the royalty clause of the lease. To argue that the juristic reason only justifies the payment of a royalty on 25 percent of production is simply a bootstrap argument that must draw its substance from one of the two earlier arguments.

A more convincing argument seems to have been adopted by Miller A.C.J., who seems to have suggested that the parties that really suffered a deprivation here were not the actual plaintiffs on the counter-claim but the other lessors who were suffering drainage and could do nothing about it. But there are several difficulties even with that approach. First, the other lessors did not in fact suffer a deprivation because the lessee agreed to pay them a royalty in accordance with the pooling clause that they each agreed to include in their respective leases. Secondly, it does not appear that the other lessors commenced an action seeking this relief. The final objection to this approach is perhaps the most far reaching. Begin by making the counterfactual assumption that the other lessors in fact received no royalty; suppose further that they commenced an action against the defendants based upon an unjust enrichment. Would not the rule of capture provide a juristic reason for the enrichment? If the rule of capture did not provide a juristic reason (which seems to have been the assumption of Miller A.C.J.) then is it not possible that Borys-type cases may be decided differently, to the extent that defendants in the position of Imperial Oil in that case are actually enriched by the incidental production of the plaintiff's gas (i.e. where they are able to save and sell the gas)? This, it must be admitted, is clearly a far-reaching view of the consequences of the Court's cryptic observations on unjust enrichment, but I would suggest that it is an inevitable consequence of this line of analysis.

In summary therefore, Foralta Resources provides limited support for the proposition that even in the absence of a pooling agreement, or a compulsory pooling order, a court may still have a basis for sharing production between the different tracts within the DSU. Howevep, each of the three grounds advanced to support this proposition is fraught with some difficulty. In these circumstances it may be more profitable to ask whether or not the compulsory pooling provisions of the Oil and Gas Conservation Act provided a potential solution to the problem and, if not, whether there is a case to be made for their amendment. 
This litigation arose because the lessee was unable to obtain a pooling or allocation agreement that would bind the lessor of the northwest quarter section. In part this was because the original lease had no, or an inadequate, pooling clause. Notwithstanding the later decisions of the Supreme Court in Gunderson and Gibbard, it is hard to criticize the lessee too strongly for this omission since, at the time the lease was negotiated, the spacing unit for either an oil or a gas well was forty acres. It is therefore not unreasonable to suggest that Foralta ought to have had access to the compulsory pooling provisions of the Act on the present facts. As we have noted, the Board took the view that Foralta did not need a pooling order since it already had the right to drill and produce throughout the DSU. This may be an unduly narrow interpretation of the Act.

The Act does not provide that a compulsory pooling order will only be available if the applicant would be unable, without it, to obtain a well licence. The Act merely requires, in s. 72(2)(c), that an applicant (who must be the owner of a tract) must state "that an agreement to operate the tracts as a unit cannot be made on reasonable terms." Although this is merely a procedural requirement, the Board, in effect, through its past practice, ${ }^{69}$ has treated it as a condition precedent to the grant of a compulsory pooling order. In the present case, arguably, Foralta could not cross the threshold since it was the only party with a working interest in the property. However, there are several arguments that might be made on behalf of Foralta. The first is that s. 72(2)(c) is quite generally framed. It does not state that an agreement between the owners of the tracts cannot be made on reasonable terms. It simply provides: "that an agreement to operate the tracts as a unit cannot be made on reasonable terms." Presumably, part of operating the tracts as a unit involves an allocation of production for both the working interest holders and the royalty interest holders. ${ }^{70}$ In the present case Foralta was manifestly unable to negotiate a "reasonable" agreement with the lessors of the northwest quarter. Secondly, it is not clear that the Board should be entitled to fetter its discretion by interpreting an informational requirement as a condition precedent, especially where the result may conflict with one of the long-standing stated objectives of the Act, namely that it is "to afford to each owner the opportunity of obtaining his share of the production of oil or gas from any pool." ${ }^{171}$ In the present case, the lessors of the other quarter sections could have been deprived of their entitlement in the absence of a production allocation or pooling agreement.

In conclusion therefore, I am suggesting that the Act could reasonably bear an interpretation that would have permitted Foralta to have had its application adjudicated

Canada Energy Law Service, supra note 3 at paras. 164-65.

That is surely confirmed by the language of $\mathrm{s}$. 79 of the Act, quoted infra, accompanying text to note 147.

Section 4(d). It should be noted that the term "owner" is specifically defined for the purposes of Part 12 of the Act. It is not defined for the purposes of section 4 of the $A c t$ where it presumably may have its natural and broad meaning and surely encompasses the owner of the corporeal estate as well as the working interest owner. 
by the Board. Indeed, for the Board to reject the application on the basis that it was not necessary may have been a reviewable error for the reasons given above. ${ }^{72}$

This admittedly lengthy excursus on the doctrine of equitable pooling has been required as a result of the decisions and reasoning of the courts in the Foralta Resources case. In effect, the decision questions the need for a pooling agreement in many of the situations in which, as the next part demonstrates, the lease seems to require one.

\section{NEED FOR A POOLING AGREEMENT: LEASE REQUIREMENTS}

Although we have proceeded thus far on the basis that the most important function of the pooling agreement is to provide working interest owners with a mechanism for complying with the spacing requirements, it is clear that working interest owners will also wish to ensure that the resulting agreement both complies with, and does not prejudice their position under, the terms of their title documents, i.e. their leases. In most of what follows in this part we shall be concerned with freehold leases. Different considerations apply to Crown leases. ${ }^{73}$

\section{A. THE POOLING CLAUSE IN THE FREEHOLD LEASE}

Given that spacing regulations will often preclude operations on a particular lease, it is axiomatic that every well-drafted lease should: (1) permit pooling; (2) ensure that all operations (drilling, production, re-working etc., and the existence of a shut-in or uneconomic well) have the same effect if carried out on the pooled lands as they would

An appeal from a decision of the Board lies to the Court of Appeal on a question of law or jurisdiction: Energy Resources Conservation Act, R.S.A. 1980, c. E-11, s. 44.

Pursuant to s. 95(1)(a) of the Mines and Minerals Act, R.S.A. 1980, c. M-15, a lease is continued beyond the end of the primary term as to that part of the location of the lease that is within, inter alia, "the spacing unit for a producing well." Neither the Act nor the Petroleum and Natural Gas Agreement Regulations (Alta. Reg. 188/85 as am., S. 23) require the applicant to provide notice of a pooling agreement to support an application for continuance. However, the disposition policy of the Crown is designed to minimize different tract ownership in those situations in which the DSU is divided between Crown and private ownership. Section 16(a) of the Act allows the Minister to issue an agreement on application rather than through a bidding process if "warranted in the circumstances." The current interpretation of that discretion is provided by the Department's Information Letter 86-35 which provides that:

By policy pursuant to section 16(a) of the Mines and Minerals Act, the minister may issue, upon application, a lease of the undisposed Crown petroleum and natural gas rights in a drilling spacing unit where mineral ownership is divided areally between the Crown and freehold.

An application for a petroleum and natural gas lease is accepted only from an individual or corporation which controls the freehold portion within a drilling spacing unit that is less than a quarter section. To certify that the applicant controls the petroleum and natural gas rights in the freehold portion of the spacing unit, a completed statutory declaration to that effect must be attached to the application.

Continuance of leases for the entire DSU has occasioned some concerns for the Department where there are extended two section spacing units in effect. See the decision of the Board in ERCB Decision D 90-11. See also Part 9 of the Act dealing with the unit operation of minerals. 
if carried out on the leased lands themselves; and (3) provide for an allocation of production for the different tracts that make up the DSU for the purpose of determining the royalty that is payable. If the lease is well drafted from the perspective of the lessee, operations on the pooled lands will extend a freehold lease beyond the end of the primary term as to all horizons, not just the pooled horizons. ${ }^{74}$ Not all leases have met this minimum standard as the old decision in Gunderson illustrates. ${ }^{75}$ In that case, the Supreme Court of Canada ruled that the pooling clause in the lease had failed to anticipate the situation of the shut-in gas well that was not on the leased lands but on the northeast quarter of the same section. Consequently, the lease terminated at the end of the primary term notwithstanding Shell's attempts to effect an internal pooling by sending a notice of pooling to Gunderson, after the well had been drilled, but before the end of the primary term.

\section{B. THE POOLING AGREEMENT AS PART OF THE CHAIN OF TITLE}

When the lessee needs to rely on operations carried out on the pooled lands rather than the leased lands, it follows that the pooling agreement becomes an essential part of the chain of title that the lessee must adduce in order to establish that its lease has

This claim turns upon the language of the lease. There is no direct authority for the proposition in the context of pooling. In the context of unitization, see Voyager Petroleums Lid. v. Vanguard Petroleums Lid. (1982), 17 Alta. L.R. (2d) 212 at 234-35 (Q.B.), affd (1983), 27 Alta. L.R. (2d) 1 (C.A.) [hereinafter Voyager]; and Esso Resources Canada Lid. v. Pacific Cassiar Ltd. (1986), 45 Alta. L.R. (2d) 1 (C.A.) [hereinafter Esso Resources]. A different result would no doubt be reached on the basis of the language of the PanCanadian lease form, one of the few widely available lessor's forms:

9. Pooling: -

Upon written notice to the Lessor, the Lessee may at any time and from time to time pool such geological formation or formations of the said lands as may be necessary to form a spacing unit with other lands adjoining the said lands. In the event of such pooling, the production of the leased substances from the portion of the said lands placed in such spacing unit shall be deemed to be that proportion of the total production from the spacing unit which the area of the said lands bears to the total area of the lands in such spacing unit, and the Lessor shall receive royalties on such proportion of total production. Drilling for, or production of, or the presence of a well capable of production in paying quantities of, any of the leased substances from any geological formation or formations included in such spacing unit shall have the same effect in continuing this Lease in force during the term of this Lease as to all the said lands as if such drilling was on the said lands, such production was from the said lands or such well capable of production in paying quantities was on the said lands, provided, however, that if at the expiration of the primary term none of the leased substances is being produced or is capable of production in paying quantities from the said lands from a well thereon, this Lease shall thereupon terminate except as to the geological formation or formations included in such spacing unit.

Supra note 65; see also Pan American Petroleum Corporation v. Potapchuk and Scurry-Rainbow Oils Limited (1964), 46 W.W.R. 237 (Alta. S.C.T.D.), aff d (1965), 51 W.W.R. 700 (Alta. S.C.A.D.), aff d (1965), 51 W.W.R. 767 (S.C.C.) [hereinafter Potapchuk] (attempt to amend/clarify the pooling agreement failed as against a top-lessee who was on title prior to the amendment). 
continued beyond the anniversary date of the last delay rental payment during the primary term or beyond the end of the primary term. ${ }^{76}$

\section{Onus}

Where a pooling agreement is essential to extend the lease there is clear authority to the effect that "the law as to the onus is that, there being no production from the said [leased] lands directly, the defendant [the party seeking to rely on the pooling] has the onus of establishing, on a balance of probabilities, that pooling of the spacing unit lands existed, such as to constitute valid drilling operations (and subsequent production) within the primary term of the [lease]." ${ }^{77}$

\section{Necessary Parties}

Is a pooling agreement effective for the purpose of extending the lease if it is not executed by all the persons who have a working interest in a tract in the relevant DSU? This question has arisen in a number of cases, but before analyzing those decisions I will consider the question from the perspective of the lessor. The lessor's main interest in encouraging pooling lies in ensuring that operations can be carried out somewhere within the DSU of which her lands form a part (or tract). The lessor has a further interest in ensuring that production revenues are divided equitably between tracts for the purposes of calculating royalties. Finally, it seems reasonable to suggest that the lessor might have an interest in being entitled to satisfy herself that there is a pooling agreement in existence, at least insofar as the lessee relies upon it to extend the lease. This latter point would require that a lessor have notice of, and have a right to obtain a copy of, any pooling agreement and amendments thereto. This latter is clearly not prevailing leasing practice, and, in the absence of a set of judicially implied terms, would need to be dealt with by appropriate drafting. The issue is discussed below.

\section{The Case Law on Necessary Parties}

The question of who is a necessary party to a pooling agreement for the purposes of extending the lease first arose in Gibbard. ${ }^{78}$ Gibbard is the companion case to Gunderson since it involved the same section of land. In Gibbard, the pooling clause authorized pooling "when such pooling or combining is necessary in order to conform" with the regulations. As already noted in the discussion of Gunderson, Shell had purported to pool the lands by giving notice of an internal pooling. Subsequent thereto, the Supreme Court ruled that even if the lands had been pooled, the lease had not been extended but had expired at the end of its primary term which date was prior to the date on which notice to pool had been sent to the lessor. Following the decision in Gunderson, Shell (presumably in an attempt to preserve its other leases in the section), applied for and obtained an order from the Conservation Board establishing a special 
spacing unit consisting of three quarter sections. Nevertheless, the lessor in Gibbard still alleged that its lease to Shell had ended with the primary term since there was no production on the leased lands.

The decision of the Supreme Court in Gibbard turned entirely upon whether the pooling that occurred there was a pooling as contemplated by the lease, or, more specifically, "whether, in the circumstances in this case, pooling or combining was necessary in 1959 to conform with the regulations." 79 Following a strict contra proferentum construction, the Court ruled that since pooling was not "affirmatively required" by the Board, the pooling clause was inapplicable. In reaching this conclusion the Court was in substantial agreement with the Appellate Division of the Supreme Court of Alberta. ${ }^{80}$ That conclusion does not concern us here. More to the point is Johnson J.A.'s consideration in the court below (speaking for a five member Appellate Division) of the lessor's argument that the pooling could not be effective because, at the time the notice to pool was given, the Gunderson lease had already reached the end of its primary term ${ }^{81}$ and therefore an essential element of a valid pooling was missing (the agreement of the lessee of one of the tracts within the DSU). That, said Justice Johnson, was a good argument:

The first point is whether a pooling of four quarters which became invalid as to one can be considered good as to the other three. Aside entirely from the provisions of The Oil and Gas Conservation Act, 1950 , ch. 46, ... I do not think that a pooling which becomes ineffective as to part can be considered valid as to the balance. ${ }^{82}$

No reasons were given for reaching this conclusion but it would seem that there are two possible justifications. First, to pool only part of the DSU is not pooling as contemplated by the lease. Hence it is not so much that the pooling is invalid as that it is not a pooling which is effective to extend the lease. Secondly, if in this case there were a pooling agreement rather than an internal pooling one might, depending upon the drafting of the agreement, reasonably reach the conclusion that it would be ineffective unless executed by all parties since that must have been the intention of the parties. Even if the agreement does not explicitly provide that it will only become effective when executed by all the parties, this may reasonably be inferred from the entirety of the agreement. This is a less convincing explanation in the case of an internal pooling, for the working interest owner probably wished to pool all, or the greatest area possible, as evidenced by Shell's application to the Board. Nevertheless, the Court of Appeal's decision provides limited authority for the proposition that a pooling agreement will ordinarily only be effective to extend the lease, provided that it is an agreement between working interest owners representing all the tracts within the DSU. Ballem certainly agrees with this conclusion and adds the following comment: 
Having regard to the purpose of pooling, it would seem that the better view is that suggested by Johnson J.A. that an incomplete pooling is ineffective. It is certain that the position of the lessor could be adversely affected by an incomplete pooling which would continue the lease indefinitely even though lessee [sic] is not in a position to produce the well. ${ }^{\text {s3 }}$

The question of whether or not all the necessary parties had executed the agreement arose in a different way in the much more recent decision of the Court of Queen's Bench in Panco. ${ }^{84}$ The facts were as follows. Amoco and HBOG were the registered legal lessees each as to a 50 percent undivided interest in a Crown lease, a portion of which included the west half of the section of land in question. Certain other parties, including Encor, ${ }^{85}$ held undivided equitable interests in the lease. The east half of the lands in question was freehold. The defendant held the entire undivided interest to the east half under a total of seven leases, three of which were for undivided interests in the southeast quarter. A well was spudded in and completed on the northeast quarter. No well was ever drilled on the southeast quarter. As framed by the parties, the case turned in large measure on whether there was a pooling agreement in place by the click date of one of the three freehold leases for the southeast quarter.

One of the attacks made on the pooling agreement by the plaintiff was that "Encor was a necessary party to that agreement, and without them being a named party there is no valid agreement. ${ }^{186} \mathrm{On}$ its face, the claim that absence of authority might go to the validity of the agreement is a remarkable one when mounted by a stranger to the contract, and it was correctly rejected by Rooke J. He gave two grounds for rejecting the argument. The first was that Encor had subsequently ratified the agreement. ${ }^{87}$ The second reason is of more interest here. Even if Encor had not ratified the agreement, its failure to ratify could not jeopardize its validity vis-à-vis the plaintiff. At most, that was a matter between Amoco and Encor. This seems to be entirely appropriate on the facts of the particular case but one must be careful not to generalize too far. The plaintiff's attack was ill-founded because the pooling agreement had been executed by the registered lessee. It does not follow that all third party attacks will fail. The plaintiff in the present case was not a mere third party. It may have been so in a contractual sense but, as the successor in title to the lessor's interest, it had a profound legal interest in the lessee's chain of title and therefore in the adequacy of the pooling agreement. Indeed, if one frames the relevant question as being whether "this was a pooling as contemplated by the lease," it is clear that the relevant privity doctrine is that of estate rather than that of contract. ${ }^{88}$ At most, therefore, Panco decided that a third

Supra note 3 at 176.

Supra note 76.

Ibid. at 348, agreed statement of facts, item (2).

Ibid. at 368.

Ibid. at 365 .

There is a question here that needs to be resolved sometime: does the doctrine of privity of estate apply to a profit à prendre of uncertain duration (i.e. a fixed term primary term followed by a term calculated by reference to the capacity of the property to produce in paying quantities)? Berkheiser v. Berkheiser, [1957] S.C.R. 387, following Martyn v. Williams (1857), 1 H. \& N. 817 suggested that the doctrine of privity of estate applied to a profit for a fixed term, (the facts of Martyn) but did not rule on the uncertain duration point. Laskin J. offered some interesting comments on the 
party cannot mount an attack on a pooling agreement on the basis that all necessary persons are not a party, at least when the agreement has been executed by all the legal working interest holders.

In addition to this issue in relation to Encor, there was also another "necessary party" question that might have merited some discussion in Panco. To develop the point I shall amplify the facts. The plaintiff in Panco sought to question the validity of three freehold leases (each as to a one third undivided interest in the southeast quarter) as to which it was now the lessor as successor in title to the lands. It was argued that the leases had terminated at the end of the primary term because no operations were carried out on the southeast quarter and it was further alleged that there was no pooling agreement in place by the end of the primary term of the first-expiring of the three leases. I shall deal below with the issue of whether or not a pooling agreement was in existence at the relevant time but, for the present, I wish to question the assumption that all parties seem to have made, ${ }^{89}$ namely, that in the absence of a pooling agreement in place by the first click date, not only did that lease fail, but all three leases failed (the so-called domino effect ${ }^{90}$ ).

In my view, the assumption is suspect for several reasons. First, Panco as the common lessee of all three leases in the quarter section did not have a problem under the Oil and Gas Conservation Act (contrary to what seems to have been assumed by the parties) just because one lease had died. It could still claim to be the person entitled to drill and produce from the quarter section by virtue of having a two-thirds undivided interest in those lands. Secondly, the ERCB's policy objective of ensuring an equitable allocation amongst the tracts could still be achieved and the interests of the excluded tenant in common (the first lessor) could be protected (albeit somewhat awkwardly)

question in Saskatchewan Minerals v. Keyes, [1972] S.C.R. 703 at 718-19, but the issue cannot be resolved here.

Evidence as to the assumption is found in two places in Rooke J.'s Panco judgment, supra note 76. First, in the introductory paragraph Rooke J. framed the issues as follows:

This is a case where the plaintiff, a third party to two purported agreements [a png lease and the pooling agreement] (to one of which it became a successor in title [the lease]), seeks to have the agreements declared of no force and effect. If either agreement is so declared, it will have the "domino" effect of invalidating three freehold petroleum and natural gas leases under which the defendant claims the right to continue to produce natural gas on a onequarter section of mineral lands to which the plaintiff now holds the fee simple title....

Later, Rooke J. (at 349-50) summarized the "agreed facts and effects" as follows:

It is acknowledged that if there was pooling [before the click date of the first-expiring lease] ... [that] lease ... would continue to be valid.... As to the other freehold leases..., they would be continued beyond their primary term by virtue of the pooling agreement being in place prior to the expiry of their primary terms ... but provided only that the [first-expiring] lease was continued by pooling prior to the expiry of its primary term.

The term "domino effect" is used at 347 of the judgment in Panco and also by Ballem in his discussion (supra note 3 at 177: "Involuntary de-pooling may also occur in a domino fashion if a lease covering lands that comprise a portion of the pooled unit is found to have terminated or lapsed, as in Gunderson." The italics are mine, but the words I have italicized suggest that Mr. Ballem had in mind a different situation from the one described in Panco). 
through the law of co-ownership. ${ }^{91}$ This would follow because Panco would be entitled vis-à-vis Dome/HBOG to the full areal allocation of production for the quarter section. Thirdly, although one result of the death of the lease might well be a breach of the terms of Panco's warranties in the pooling agreement, is it clear that such a breach is sufficient to "invalidate" the pooling agreement or to justify a declaration that the agreement is "of no force and effect"? Surely not; or at least one should not reach that conclusion without a close examination of the pooling agreement in question.

The question that we have been addressing in this section of the article is: "who is a necessary party to a pooling agreement for it to qualify as pooling within the terms of the title documents (the lease)?" We have seen that Gibbard is authority for the proposition that pooling must include all the tracts within the DSU. This seems entirely appropriate, for without the inclusion of all the tracts within the DSU the property cannot be produced and the objectives of the lessor have not been met. It follows that a partial pooling is not the type of pooling that the lease might have contemplated. Panco, in its assumptions, goes further and suggests that the only valid pooling agreement is an agreement executed by the working interest holders of the entire 100 percent undivided interest for each tract. I have suggested that such a conclusion is too broad and is not required either by the Oil and Gas Conservation Act, or as a matter of policy. Neither is it required as a rule of law applicable to pooling agreements, although I would concede that a pooling agreement might well be drafted in such a way as to make this requirement a condition precedent to the validity of the agreement. Finally, we have seen that Panco suggests that a third party is not in a position to attack a pooling agreement on the grounds that it was not executed by all the necessary parties, at least where the agreement has been signed by the legal lessees for all the tracts of the DSU.

\section{CERTAINTY, NOTICE AND FORMALITY REQUIREMENTS}

\section{Certainty}

As with all contracts, a pooling agreement must meet a test of certainty. Hence, a mere agreement to agree to pool may be unenforceable, ${ }^{93}$ as may an agreement that omits essential elements. These issues have all been raised by the litigation in the Panco and Gas Initiatives cases.

There would still be a duty to account to other owners of undivided interests within the tract for more than the proportionate share of royalties or production received: Job v. Potton, supra note 40.

A contractual analysis of this problem would ask whether or not the breach was a breach of a condition or was otherwise serious enough to allow the innocent party to accept the breach as a repudiation: Hongkong Fir Shipping Co. v. Kawasaki Kisen Kaisha Lid., [1962] 2 Q.B. 26 (C.A.). See also the discussion infra in the accompanying text to note 110. 
The Gas Initiatives ${ }^{94}$ decision presents difficult problems of analysis primarily because of the unusual disposition of the case by the Court of Appeal, which reversed the written decision of Moore J. (as he then was) with the following cryptic note in the law reports: "reversed ... with the written consent of the applicants without written reasons."195 The facts, briefly, were as follows. The plaintiff, GIV, held a five year petroleum and gas lease from Beck for the northwest quarter. At the end of the primary term, 17 May 1978, no well had been drilled on the lands but a gas well had been drilled on the southeast quarter section and completed on 23 October 1973. The well had been drilled by Bow Valley, which was the lessee of the southwest quarter section. Prior to drilling the well, Bow Valley entered into individual letter agreements with each of the lessees of the other three quarter sections. Each of the letter agreements purported to effect both a farmout to Bow Valley and a pooling, the operative clause reading as follows:

6. Upon having drilled the test well pursuant to Clause 2, Bow Valley shall have earned an undivided $50 \%$ of Western's [GIV's predecessor in title] interest in all formations in which the test well is completed as a gas well. To clarify this, it is understood that Western agrees to pool the gas rights with the balance of the section to form a spacing unit. Western will thus have a $25 \%$ interest in the pooled section. After Bow Valley earns $50 \%$ of Western's interest, Western will retain a $121 / 2 \%$ interest in the complete spacing unit with respect to all the zones completed for gas production. Notwithstanding the foregoing, in the event the test well is dry and abandoned or is not classified as a gas well in any zones, the pooling shall terminate and Western will have no interest in the balance of the pooled section and Bow Valley will have earned no interest in the option lands. ${ }^{\text {\% }}$

It is apparent that, in addition to agreeing to pool, the clause effects a crossconveyance (upon the completion of earning) insofar as each party becomes a tenant in common as to the entire DSU and (with the exception of Bow Valley) dilutes its interest in its "own" quarter section accordingly.

Subsequently, after the end of the primary term of the Beck lease, the working interest owners agreed to enter into a formal pooling agreement, but this was not executed until 18 May 1978.

On these facts, Moore J. ruled that the lease had been extended, apparently agreeing with counsel for GIV that the letter agreement constituted a binding agreement to pool that had been acted upon by Bow Valley, for without such an agreement, "Bow Valley would not have been able to drill a gas well as it required the Beck lands to form the necessary spacing unit."

\section{Supra note 26.}

$95 \quad$ Ibid. (C.A.).

\% Supra note 26 at 297 (Alta. S.C.T.D.).

$97 \quad$ Ibid. at 298. Ballem suggests, supra note 3 at 176 that the well was licenced as an oil well and that therefore pooling was unnecessary. Be that as it may, the more fundamental point might be that Bow Valley was probably entitled to a well licence on the basis of the three bilateral agreements that it entered into with each of the respective lessees. Surely, at the very least, those agreements gave Bow Valley the right to claim to be the authorized representatives of the persons entitled to the rights to produce within the meaning of s. 13 of the Oil and Gas Conservation Act. 
Although somewhat speculative, two possible explanations for the reversal by the Court of Appeal may be posited. The first explanation is simply that the letter agreement was, in relation to the issue of pooling, nothing more than an agreement to agree, and as such, unenforceable. This seemed to have been the explanation preferred by Justice Rooke in the subsequent Panco decision and I shall deal with it in more detail, infra. The second explanation would be that only an agreement executed by the working interest owners for each tract was a pooling within the meaning of the lease. This was problematic for the plaintiff lessee in Gas Initiatives, since it appears that there were three quite separate pooling and farmout agreements that were executed by Bow Valley and each of the other three lessees to the different quarter sections. Thus, even if problems of certainty could have been surmounted, there would still have been the difficulty that GIV could only point to an enforceable agreement with one of the necessary parties. There was no agreement between all four lessees by the click date, and without such an agreement GIV could not show an entitlement to a share of the production from the well on the southeast quarter. ${ }^{98}$ Whether such an agreement was necessary takes us back to the discussion in the previous section. While an agreement might not have been necessary for the purposes of supporting Bow Valley's application for a well licence (the individual agreements to pool and the farmout agreements should have sufficed to give Bow Valley that right ${ }^{99}$ ), it was clearly necessary for the plaintiff's chain of title for that particular lease, for the reasons given above in relation to Gibbard.

The question of what constitute the essential elements of a pooling agreement arose in Panco. One of the arguments made by the defendant in that case was that a pooling agreement was in place prior to the click date of the first-expiring lease as a result of an oral agreement between the parties. Assuming that such an agreement need not comply with the Statute of Frauds (a point dealt with in more detail below), what would be the essential elements of such an oral agreement? Having considered the Gas Initiatives case, Rooke J. found that the parties had entered into an enforceable oral pooling agreement. It was not an agreement to agree ${ }^{100}$ even though the parties anticipated that a formal written agreement would follow. The written agreement contained many more terms than did the oral agreement, but the "essential elements" were agreed upon orally. In Justice Rooke's opinion, these essential elements were the identification of the lands, the use of the term "pooling," and what Justice Rooke described as an ancillary "but unnecessary" provision as to participation on a fifty-fifty basis. ${ }^{101}$ Reliance was also placed on the subsequent conduct of the parties which showed that there was substantial performance of the oral agreement on both sides prior to the execution of the written agreement. This subsequent conduct included execution

This would be the case even if Bow Valley does not become a tenant in common until after it has eamed its interest by drilling a well that is not dry, abandoned nor classified as a gas well; (see the unusual contingent language of the earnings clause (cl. 6) quoted in the text). accompanying supra note $53 \mathrm{ff}$.

Supra note 45. 
of an Authorization for Expenditure ("AFE") for a well that had already been spudded in, and the satisfaction of invoices based upon that AFE.

In all the circumstances, Rooke J.'s conclusion does not seem inappropriate but it may be useful to offer several comments. First, the "essential elements" of a pooling agreement surely include agreement on the sharing of participation in the costs of operations and the allocation of production on the basis of a principle such as reserves or surface area. ${ }^{102}$ If there were any doubts that participation was to be on anything other than an areal basis, then surely there would have been no agreement. It is therefore incorrect to describe agreement on this issue as either ancillary or unnecessary; it is one of the core elements of the agreement. Secondly, one assumes that there was, in addition to what Rooke J. described as the "essential terms," further agreement (either express or based upon a custom in the industry) amongst the parties, that Panco would be designated as operator, that operations on the lands would be conducted in accordance with the current version of the CAPL operating procedure, and that Amoco would execute an AFE for a well that had already been drilled. Some of these assumptions may well be questionable, such as which version of the CAPL operating procedure the parties had agreed to use, but is hard to escape the conclusion that all these elements ought to have formed part of the oral agreement between the parties.

\section{Notice Requirements}

There are several issues that arise under this heading. First, in the absence of a provision in the lease requiring the lessee to provide notice of pooling decisions, is it possible to imply such a requirement? Secondly, if the lease requires notice, what is the consequence of a failure to comply?

\section{a. An Implied Duty?}

Many lease forms do not require the lessee to give notice to the lessor that it has entered into a pooling agreement. Furthermore, although there is some division of judicial opinion, the prevailing view where the lease is silent is clear: the failure to provide notice is "immaterial" and the courts are not prepared to read in a requirement to give notice, either on the basis of an implied covenant or on the basis of an alleged industry custom. This was the view of Moore J. in the Gas Initiatives case. ${ }^{103}$

A different view had been taken by the Court of Appeal in the Gibbard case. ${ }^{104}$ In seeking to establish a valid pooling in that case, the lessee had made two arguments. The first argument, dealt with above, was that the notice of a full four quarter section

In the absence of a cross-conveyance as part of a pooling agreement (see discussion in accompanying text to infra notes 117ff) or adoption in Alberta of the American doctrine of equitable pooling (see discussion in accompanying text to supra notes $53 \mathrm{ff}$ ) there is no other legal basis on which to share production; the entire production would be attributable to the tract on which the well is drilled. 
internal pooling was sufficient to extend the lease. That argument failed because of the Court's conclusion that pooling was not "necessary" within the meaning of the lease. The lessee then argued, in the alternative, that a new pooling had taken place ${ }^{105}$ as to three quarter sections when the Board granted a special spacing unit order for three quarter sections, or later when a shut-in royalty cheque was tendered. Johnson J.A. for the Court of Appeal rejected all these arguments. Pooling was not coincident with the Board's spacing unit order. Rather, it is "something which must be done to make the pool correspond with the spacing unit." 106 Johnson J.A. went on to say, on the same page:

Pooling must, I think, be an overt act evidenced either by notice or otherwise. This was recognized when the pooling notice of 1955 was given. The words used are significant - Shell Oil Company "hereby pools and combines the said quarter section." That would be a "pooling declaration" of the kind mentioned in cases from states in the United States from which this type of clause originally came.

When the appellants seek to extend the lease beyond its primary term by some act required to be done by the lessee - in this case pooling of the lands with other lands - proof of such act must surely be necessary. The only pooling which has been proved is the invalid one of 1955 . There is therefore no proof of a pooling which would continue the lease beyond its primary term.

Although the logic of this position is compelling, especially since the pooling in question was an internal pooling, it did not find favour with the Supreme Court of Canada. Despite generally upholding the reasoning of the Court of Appeal, Locke J. went out of his way to remark that he was:

unable to agree with the opinion of Johnson, J.A. that any formal written notice of the election of the lessees to exercise the option to pool was necessary. That the lessees had elected to exercise the option was, in my opinion, sufficiently indicated by the application to the board to fix the special spacing unit in May, 1959, and the letters directed to the respondent enclosing the royalties to which he would have been entitled had the pooling been effective. ${ }^{107}$

Consequently, it seems to be clear law that, where the lease is silent on the question, the lessor is not entitled to notice of a pooling.

\section{b. A Notice Requirement in the Lease}

One example of a lease form that does require a written notice is the PanCanadian lease form quoted above. ${ }^{108}$ That lease provides that the lessee may pool "upon giving written notice to the lessor." What is the consequence of a failure to do so? The answer should, in principle, depend upon the correct construction of the relevant clauses of the

Ibid.

Supra note 64 at 535.

See supra note 74. See also the CAPL lease form, supra note 6 and the Shell lease form discussed infra. 
lease in question. There are two main possibilities. The first is that continuation of the lease through pooling is an additional option available to the lessee. It is therefore analytically similar to the delay rental and shut-in royalty options under the traditional "unless" lease. A failure to comply with the requirements of the option has the usual draconian consequences and the lease fails. ${ }^{109}$ Based upon its conditional opening language, the PanCanadian lease might bear this interpretation, but a stronger case might be made for the Shell lease. The pooling clause in the Shell lease accords the lessee the right to pool in paragraph (a) and then, in paragraph (b), states that: "The lessee shall be entitled to exercise the rights and powers given by subclause (a) hereof by giving to the lessee written notice." The natural interpretation of this clause is that pooling is not complete until written notice has been given.

The second possibility is that the failure to give notice is simply a breach of the lessee's obligation for which the lessor might have its usual range of remedies. A close analogy might be with the landlord and tenant case law on assignments and sublets. That case law establishes that an assignment or sublet without the consent of the lessor (where required by the lease) is not void or of no effect, it is simply a breach of the lease for which the landlord has her usual range of remedies including the right of reentry for breach of a covenant. ${ }^{110}$ The same might apply to the failure to comply with a lease term requiring that notice be given of a pooling agreement. On this argument, the pooling agreement would be effective not just as between the parties, but also effective to extend the lease beyond the end of the primary term. This last point suggests that the landlord and tenant analogy is not precise, for it should be noted that the lessor's right of re-entry for breach under an oil and gas lease is ordinarily quite seriously circumscribed by the lease terms. ${ }^{11 \prime}$ If the lessor is put to proof of damages it is hard to imagine a situation in which damages would be more than nominal.

A lease that demands this second interpretative approach is the CAPL lease form. ${ }^{112}$ That lease accords the lessee the right to pool and then, in a separate sentence, states that the "Lessee shall thereafter give written notice to the Lessor." The contrast between the drafting techniques in the Shell and CAPL lease forms is strong. In the case of the Shell lease, notice appears to be a condition precedent to valid pooling, whereas in the case of the CAPL lease, notice is a mere formality, for the pooling is already effective.

In summary therefore it is clear that where the lease is silent, notice of pooling is not required, whether the pooling is arm's length or internal. Some leases do require notice but the consequences of a failure to provide notice are not clear. Given the importance

On the "unless" lease and delay rentals see East Crest Oil Co. v. Strohschein and Strohschein (1951), 4 W.W.R. 553 (Alta. S.C.A.D.). On the effect of a late shut-in royalty payment see Canadian Superior Oil Lid. v. Hambly (1970), 74 W.W.R. 356 (S.C.C.). For general commentary see Ballem, supra note 3. is a well capable of production on the leased lands or the pooled lands. See e.g. clause 15 of the CAPL lease, supra note 6. 
of the effect of pooling it does not seem unreasonable to suggest construing the pooling clause as an option and thereby demanding strict compliance. Obviously, however, this is primarily a matter of the proper construction of the lease form.

Although lessees will naturally wish to avoid a notice requirement, it seems reasonable for those advising lessors to stipulate for written notice of pooling and for a copy of the executed agreement. The main justification for this claim is simply that the pooling agreement is an essential element of the lessee's chain of title in the absence of operations on the leased lands. For the same reason, and although no doubt unpopular with lessees, a lessor might also insist upon a lease term to the effect that the failure to comply will result in the lease not being extended beyond the end of the primary term where the lessee is relying upon operations on the pooled lands rather than the leased lands. This requirement may be particularly appropriate for an "internal" pooling, such as was the case in Gunderson and Gibbard.

\section{Formality Requirements}

In the ordinary course, the usual evidence of the existence of a pooling agreement will be the counterpart execution (including delivery ${ }^{113}$ ) of a written agreement. The case law however reveals two types of difficulties. First, does a pooling agreement need to comply with the Statute of Frauds, ${ }^{114}$ and secondly, are there alternative methods of proving the existence of a pooling agreement, especially where the pooling alleged is an internal pooling, i.e. where the working interest in the tracts of the DSU is held by the same party but from multiple lessors?

\section{a. The Statute of Frauds ${ }^{115}$}

Section 4 of the Statute of Frauds, if applicable, would require that a pooling agreement be in writing, or be evidenced in a writing signed by the party against whom the agreement is to be enforced. Without that evidence a pooling agreement would be unenforceable in the absence of sufficient acts of part performance by the party wishing to enforce the agreement. The issue of the applicability of the Statute ought to have been settled in the Panco case but the plaintiffs failed to plead the Statute as required by Rule 109 of the Alberta Rules of Court and therefore Rooke J. proceeded on the assumption that the agreement fell outside the Statute. ${ }^{116}$

113 For a discussion of the pooling contract as a deed and of the requirement of delivery, see Panco, supra note 76 at $359-62$.

114 (U.K.), 29 Car. II, c. 3.

I15 See generally Institute of Law Research and Reform, Report No. 44, The Statute of Frauds and Related Legislation (Edmonton: Institute of Law Research and Reform, 1985); and M.G. Bridge, "The Statute of Frauds and Sale of Land Contracts" (1986) 64 Can. Bar Rev. 58.

Panco, supra note 76 at 364,6 n. It should be noted that there were potentially sufficient acts of part performance in Panco to take the case out of section 4. Although there are perhaps still doubts as to what will suffice for part performance, the usual assumption is that the test has been somewhat relaxed following the House of Lord's decision in Steadman v. Steadman, [1976] A.C. 536 (H.L.). This certainly seems to have been the assumption of Chrumka J. in the recent case of Conmac Western Industries v. Robinson (1993), 9 Alta. L.R. (3d) 232 at 310 (Q.B.). See also C. Boyle \& D.R. Percy, Contracts: Cases and Commentaries, 5th ed. (Toronto: Carswell, 1994) at 
Whether or not a pooling agreement is within the Statute ought to depend upon the legal effect of the agreement which ought, in turn, to depend upon established legal doctrine and the intentions of the parties ${ }^{117}$ as revealed by the language used. There appear to be two main options in characterizing the effect of a pooling agreement. The first possibility, which I shall term "functional pooling," is simply that the agreement has achieved the basic objectives of pooling but nothing more. The basic objectives would be: compliance with conservation spacing requirements and apportionment of expenses and production. The second possibility is that the parties have gone beyond these functional requirements and have effected a cross-conveyance of the working interests that each contributed to the formation of the DSU. The result of this second approach is the creation of a tenancy in common between the parties throughout the drilling spacing unit. ${ }^{118}$ We have already encountered an example of this approach in the pooling and farmout agreement in the Gas Initiatives case. In that case, it will be recalled that, upon Bow Valley fulfilling its contractual commitments, it was to earn 50 percent of each farmor's interest, but, in addition, each farmor's interest was to become a $12 \frac{1}{2}$ percent interest in the entire section rather than a 50 percent interest in a particular quarter section.

The different approaches are illustrated by the pooling agreements that were at issue in the Panco case and in Luscar Resources Ltd. v. Pembina Resources Ltd. ${ }^{119}$ The trial judgment in the latter case also illustrates one reason why some practitioners have avoided the use of the cross-conveyance. ${ }^{120}$ In Luscar, the plaintiffs alleged that the defendants had, on a number of occasions, breached an area of mutual interest ("AMI") clause by failing to offer them the opportunity to participate. The AMI clause was triggered when a party to the agreement was "acquiring or desiring to acquire any reservation, permit, license, profit a prendre, lease, fee simple estate, royalty or other interest in petroleum substances." ${ }^{121}$ Although several transactions were alleged to have triggered the AMI, the transaction that concerns us here was a pooling agreement that the defendants (Pembina) had entered into. Pembina held a 50 percent undivided interest in a Crown lease for the west half of a section of land. It then (along with the

311, 4n; but G.H.L. Fridman, The Law of Contract in Canada, 3d ed. (Toronto: Carswell, 1994) at 234 suggests that there is continuing uncertainty.

The issue is not solely one of the intentions of the parties, since whether or not something attains the status of an interest in land is a question of law rather than merely one of the intentions of the parties, a point that is amply demonstrated by the litigation on the nature of the royalty interest. See especially First City Trust Co. v. Noble and Canadian Industrial Gas and Oil Lid. (1993), 8 Alta. L.R. (3d) 225 (Q.B.) (the GRTA Test Cases), affd (1994), 23 Alta. L.R. (3d) 433, [1995] 1 W.W.R. 137 (C.A.).

The distinction between these two characterizations should be a matter of construction and not a rule of law. Kramer and Martin acknowledge this in supra note 2 at para. 19.01 but they then go on to discuss the cross-conveyance vs. contract theories and to categorize state rules accordingly. In principle, the issue should not be one of theory or rules, but one of construction. (1991), 85 Alta. L.R. (2d) 46 (Q.B.), rev'd (1994), 24 Alta. L.R. (3d) 305 (C.A.) [hereinafter Luscar].

One advantage of a cross-conveyance is that the resulting tenancy in common provides an immediate basis for a sharing of production through an accounting, but this is hardly a sufficient reason for choosing this option. The issue of production allocation is better addressed by a separate clause in the agreement. 
other tenants in common to that Crown lease) entered into a pooling agreement with the Crown lessees for the east half. The relevant clauses to the pooling agreement ${ }^{122}$ were as follows:

\section{POOLING}

On and after the date hereof and in consideration of the terms and conditions hereof the parties hereto agree to and do hereby pool and combine all their respective rights, titles and interests in and to the pooled lands.

\section{PARTICIPATING INTEREST}

The parties hereto agree that on and after the date hereof their respective undivided participating interest shall be as follows:

\begin{tabular}{lr} 
Barnwell & $7.3875 \%$ \\
Can. Sup. & $9.8510 \%$ \\
Cayuga & $6.2500 \%$ \\
Chevron & $14.7775 \%$ \\
Francana & $12.5000 \%$ \\
Gold Lake & $8.3335 \%$ \\
Kerr-McGee & $8.4375 \%$ \\
Pembina & $25.0000 \%$ \\
Tenneco & $5.0000 \%$ \\
West Central & $1.4630 \%$ \\
& \\
\hline & $100.0000 \%$
\end{tabular}

It is evident that the result of the pooling was to effect a cross-conveyance. This conclusion follows from the language of both clauses. The pooling clause itself refers to combining "rights, titles and interests." The pooling is not confined to a particular purpose such as "to permit an application to be made for a well licence." The critical language in the third clause are the words "undivided participating interest." The word "undivided" is the hallmark of a tenancy in common, and the term "participating" confirms that the interest is to be a working interest rather than a carried interest. Finally of course, the results of pooling as stated in that same clause confirm that a cross-conveyance had occurred: Pembina took a 25 percent interest in the entirety of the pooled lands rather than retaining a 50 percent interest in the west half. That said, did this trigger the AMI clause? Egbert J., without needing to quote or otherwise refer to the terms of the pooling agreement, concluded that entering into it triggered the AMI clause and that failure to comply with the requirements of that clause constituted a breach of Pembina's AMI obligations. ${ }^{123}$ On a literal interpretation of the AMI clause, this conclusion seems correct. Pembina did acquire an interest in other lands in the

122 The pooling agreement is not reproduced in the judgment. A copy was made available to me by Aldo Argento of Parlee, McLaws, Calgary, one of the counsel for the plaintiff in Luscar.

123 Supra note 119 at paras. 20, 55-59 and 91 (Q.B.). 
AMI area. The fact that it did so by diluting an existing interest may not be relevant. By contrast, the Court of Appeal took a much narrower view of the ambit of the AMI clause. Conrad J.A. for the Court, stated as follows:

In my view, on any reasonable interpretation of the intent of the parties, that transaction was not an "acquisition" of the type referred to in Clause 18 [the AMI clause], notwithstanding it resulted in ownership of different lands. The right to those new lands is really an extension of the pre-existing acquisition. It is important to consider the nature of a pooling agreement. While it results in an interest in new lands, the right to such a new interest is derived solely from the ownership of existing lands. It is not in any way an acquisition in the open marketplace. ${ }^{124}$

Once again, however, the Court did not advert to the actual language of the pooling agreement in its judgment. The nub of the paragraph is undoubtedly the idea that not all acquisitions are "acquisitions" within the meaning of the AMI clause. I think that this has the potential to be a useful clarification of an AMI clause but, with respect, the test should not be "was this an extension of a pre-existing interest" or "was it an acquisition in the open marketplace." Surely, non-market transactions ought to be subject to the clause unless the parties expressly agree otherwise. Similarly, the fact that a new interest "extends" an existing interest is surely precisely the situation in which an AMI clause should apply. The more fundamental question might be "did the party acquire an additional interest in the area subject to the AMI clause?" If that were the test of whether or not there had been an acquisition, one might cogently argue that a pooling agreement that effected a cross-conveyance on an acreage basis did not come within the ambit of the clause.

In conclusion, on a formalistic and strict interpretation of an AMI clause, a crossconveyance pooling may well trigger an AMI clause. However, an interpretation that pays closer attention to the underlying purpose of the AMI clause may well allow the conclusion that this type of agreement was not intended to be included within the ambit of the clause. The question we must now pose is whether or not an administrative or functional pooling should trigger an AMI clause. However, before considering that question, we should note that there are other analogous questions to keep in mind. These might include the following: ${ }^{125}$ whether entering into a cross-conveyance pooling agreement triggers a right of first refusal; whether a cross-conveyance leads to land titles priority problems or requires the filing of additional caveats in order to protect new proprietary interests; ${ }^{126}$ will the assignment of an undivided interest as part of a cross-conveyance require notice to, or perhaps the consent of, the lessor

125 Kramer \& Martin, supra note 2 at para. 19.01 provide other reasons in the U.S. context. These include: who may effect a pooling; who is an indispensable party to litigation; and what is the appropriate venue for litigation. 
depending upon the terms of the lease, as well as the relevant legislation if the lease were a Crown lease? ? $^{127}$

The language used by the parties in $P a n c{ }^{128}$ provides a good example of the language typically adopted to effect an administrative or functional pooling rather than a cross-conveyance. Article II of that agreement provides:

\section{POOLING}

[A] Subject to the terms and conditions of this Agreement, the parties hereto do hereby pool their respective interests in and to the pooled substances in the pooled lands so that from and after the effective date all operations with respect to the pooled substances in the pooled lands may be conducted without regard to the boundary lines of the separate Leases comprising the said leases and as [B] though the pooled lands were covered by a single Natural Gas Lease executed by the respective Lessors of the Leases comprising the said leases as Lessor in favour of all of the parties hereto as Lessees and as if such Natural Gas Lease had been subject to all the terms and conditions of this Agreement, [C] it being the intention of the parties that each party by virtue of its interest in the pooled lands shall be entitled to receive its proportionate share of the pooled substances from the pooled lands as a whole in accordance with its participating interest as hereinafter provided, [D] PROVIDED THAT nothing in this Agreement is to be construed as effecting the cross-conveyance of interests of the parties in the respective Leases and lands contributed to the said leases and the pooled lands by the parties.

Under this agreement, HBOG and Amoco contributed the entire working interest in part of a Crown lease for the west half of the lands which they held fifty-fifty as tenants in common. Panco contributed the entire working interest in the east half, derived by it from no less than seven freehold leases.

The first part of the clause, labelled [A], states the effect of the pooling in functional terms and provides the essential basis for an application to the Board for a well licence. The second part, labelled [B], provides further interpretive guidance as to the effect of [A]. It is clearly modelled on standard unitization language and is intended to ensure that, as between the lessees, it matters not where on the DSU the well is drilled. ${ }^{129}$

This would obviously not be the case in Alberta. The Mines and Minerals Act, supra note 73, s. 27 only requires ministerial consent where the parties propose a division of the agreement. The Act facilitates transfers of undivided interests through the Crown registry established by Part 10 of the Act.

Supra note 76 . The agreement is not reproduced in the reported decision; a copy was made available to me by Harvey Locke of MacKimmie Matthews, Calgary, counsel for the plaintiff. Reasons for entering into a non cross-conveyance pooling agreement include: avoiding buying into another party's title problems; and that pooling will in some circumstances constitute a temporary arrangement, specific to a certain zone or even a well. These reasons were suggested to me by David Blain.

On and after the Effective Date the interests of each Royalty Owner and of each Working Interest Owner in the Unitized Substances and in the Unitized Zone are hereby unitized, as if the Unitized Zone had been included in a single lease executed by the Royalty Owners, as lessors, in favour of the Working Interest Owners, as lessees, and as if the lease had been 
The third part of the clause, [C], establishes the allocation principle which is dealt with more substantively in Article IV of the agreement. Subject to my earlier discussion of the status of the doctrine of equitable pooling in Alberta law, in the absence of a crossconveyance, a working interest owner's tract entitlement to a portion of production must depend entirely upon this contractual allocation in the absence of a well on its particular land. The final proviso in the clause, [D], is obviously inserted for the purposes of greater certainty and specifically to guard against the risk of a crossconveyance.

Would such an agreement trigger an AMI obligation using the language of the clause in Luscar? On a strict interpretation one would argue that in an administrative pooling the parties do not obtain "an interest in the petroleum substances" of the other parties, if by the term "interest" we have in mind a technical usage and mean in effect "an interest in land." This seems entirely appropriate if the pooling agreement is the usual acreage-based agreement. ${ }^{130}$

This lengthy excursus on the legal effect of a pooling agreement has been included in order to permit us to address the need for a pooling agreement to comply with the Statute of Frauds. One can assert with a high degree of confidence that if the agreement effects a cross-conveyance, as did the agreement in Luscar, ${ }^{131}$ then it must comply with s. 4 of the Statute. The position is less clear if the pooling is more functionally limited. On the one hand it may be argued that such an agreement does not relate to an interest in land. Certainly, a party to a functional or internal pooling agreement does not acquire a legal or equitable interest in anybody else's land. Yet on the other hand, a pooling agreement may have a proprietary effect because it may result in an extension of the lease and is part of the lessee's chain of title. For this reason, and because of the importance of the lessor being able to satisfy herself as to the pedigree of her lessee's title, I incline to the view that even functionally limited pooling agreements should be required to comply with the Statute. ${ }^{132}$

\section{b. Internal Pooling}

Notwithstanding the above conclusion, there is support in the case law for taking a more relaxed approach where the pooling that is alleged is an internal pooling. It is

subject to this agreement....

Quoted from Voyager, supra note 74 at 216 (Q.B.).

130

Should it make a difference if the parties have pooled on a reserves basis and the party subject to the AMI obligations has acquired a production allocation that is more favourable than that which would prevail under an acreage allocation? Here I think that there are too many variables to give an adequate response. If the reserves allocation was justified, in whole or in part, on the basis of information derived from the jointly owned property, that might provide some basis for subjecting the transaction to the AMI obligations. If not, then it is less clear why the other parties should be entitled to participate. Perhaps the issue ought to be dealt with in the drafting of AMI clauses by excluding acquisitions by way of pooling agreements confined to single DSUs. effect a cross-conveyance, at least between the farmor and each of the farmees individually. 
hard to fathom the logic of this position if one concedes that the lessor has a legitimate interest in the question of pooling. The issue received passing mention in dicta in the Gibbard case (discussed above under the heading "Notice"133) but has been more specifically treated in the recent decision in Mesa Operating Ltd. Partnership v. Amoco Canada Resources Ltd., ${ }^{134}$ a case that is dealt with in much more detail below.

The facts in Mesa were as follows. Dome (succeeded by Amoco) held a 100 percent interest in a Crown lease for the north half of the section. It also held legal title to the Crown lease for the south half of the section, and managed the $12 \frac{1}{2}$ percent interests of Maligne and TCPL (and subsequently just that of TCPL) in the south half lease. Maligne's interest was ultimately acquired by Conwest in 1983 but by then Dome had drilled a one section DSU gas well on the south half (1980-1981). No formal written pooling agreement was entered into with any party prior to a 1990 agreement with Conwest. In litigation over royalty payments and the allocation of production, Mesa, which held a royalty interest in the south half but not in the north half, alleged that the section had never been pooled and that therefore the royalty should be calculated on the basis of 100 percent of production from the well on the south half. By way of response, Dome argued that there was an internal pooling prior to production since this was necessary in order to conform with "government regulations and industry practice." 135

Shannon J. rejected Mesa's argument on this point with very little supporting reasoning. He simply observed that:

This court finds that Dome did, in fact, pool the two half sections albeit informally by way of an internal pooling. An examination of its internal records and the documents it filed with government agencies leads to no other conclusion. ${ }^{136}$

Shannon J. suggested two reasons for finding that there was a pooling agreement: (1) internal records and (2) filings with government. The internal records of Dome did indicate a pooling. The records referred to an "internal pooling," and drilling and other costs were allocated on a fifty-fifty basis between the north and south halves. Furthermore, Dome's accounting records showed each of TCPL and Conwest entitled to a diluted interest in production of 6.25 percent, which signified pooling on an areal basis. In the absence of a well on the north half, there was no other basis but through a pooling agreement, upon which they would be entitled to any share of production. The record of government filings does not seem to have been as compelling. ${ }^{137}$ The well licence application for the 3-4 well was equivocal since there was evidence to the effect that the ERCB accepted well licence applications as long as the applicant had the

The Supreme Court of Canada in particular seems to have been satisfied with minimal formality requirements for an internal pooling. (1992), 129 A.R. 177 (Q.B.), affd (1994), 149 A.R. 187 (C.A.) [hereinafter Mesa].

Ibid. at 213 (Q.B.).

Ibid. at 221. The issue was not dealt with by the Court of Appeal.

137 Shannon J. does not provide much guidance as to which part of the evidence on this point that he found to be compelling. 
rights to the oil DSU in question. ${ }^{138}$ The main evidence for pooling therefore would have been Dome's notice to the ERCB of Commencement of Production for a gas well, at which time an internal pooling would have been inferred.

Taken together, this does provide evidence that Dome treated the lands as pooled. However, the case does not answer the question of whether a pooling of this nature should bind a third party lessor where the existence of a pooling agreement is part of the chain of title. ${ }^{139}$ In considering the authority of the case, it should be noted that the validity of the leases in question did not depend upon the existence of a pooling agreement. Both leases were Crown leases and were therefore continued beyond the end of the primary term merely by the existence of a well on the DSU that was, in the opinion of the minister, capable of production. ${ }^{140}$ Proof of pooling was therefore not required for the chain of title. Furthermore, pooling was not strictly necessary in order to apply for a well licence (Dome had a working interest throughout the DSU) although, as we have seen, as a matter of policy the ERCB might have refused to issue the licence if it were aware that ownership interests differed from tract to tract in the DSU. From Dome's perspective however, pooling was clearly required in order to allocate production between the two tracts in order to satisfy both the different working interest owners and Mesa as a royalty holder. In my view therefore, while Mesa supports the proposition that internal poolings may be informal in some circumstances, the case may not be persuasive in a case that raises a lease continuance problem.

\section{POOLING AND NON-PARTICIPATING INTERESTS}

Thus far this article has merely touched upon the question of the duties owed by the working interest owner to other persons holding non-participating interests in the property when entering into a pooling agreement. It is now necessary to consider that question in a more systematic manner. To this point we have only considered the position of the lessor and have noted that the duty owed to the lessor by the working interest owner is very limited. Indeed, in the absence of an express provision in the lease, there is not even a duty upon the lessee to provide the lessor with notice of pooling. I am not aware of any lease form requiring the consent of the lessor before the lessee enters into a pooling agreement. ${ }^{141}$

See ERCB Informational Letter IL-OG 75-14. This Letter indicates that "The Board is now prepared to license a well under Section 2.020 of the Oil and Gas Conservation Regulations if the applicant has the rights to the oil well spacing unit on which the well is located.... However, the Board will require the licensees of a gas well to confirm, prior to placing the well on production, that he has the right to produce from the entire gas well spacing unit whenever such is not indicated on the well licence application."

Mesa of course was a third party, but its only interest was as the holder of a royalty, not as lessor. See also the Foralia Resources case, supra note 19 which provides a somewhat analogous fact pattern.

141 One of my reviewers, supra note 1 indicated that he had drafted such a clause into a lease on behalf of a client lessor with significant mineral holdings. This is clearly an exceptional circumstance at the present time. 
The position of owners of other non-participating interests, such as the owners of gross overriding royalty interests, is no different. Documents creating the royalty interest will often accord the grantor the right to deal with the property and to enter into pooling agreements without the consent of the royalty owner. However, even if the document is silent, a court would not create an implied requirement of consent, for to do so would be inconsistent with the non-participatory nature of the interest. Managerial decisions of this nature lie within the province of working interest owners, as the tenants in common, sharing the unity of possession. Even if a royalty interest fails to be classified as an interest in land, it will usually not amount to an undivided interest in the property. ${ }^{142}$

\section{A. LEASE REQUIREMENTS}

Consent, however, is just one issue. Equally, we need to inquire into the scope and extent of other possible duties that may be owed to the non-participating interests by the holder of the working interest when negotiating or implementing a pooling agreement. Obviously, a critical concern of the lessor will be the fairness of the allocation of production to each participating tract for the purposes of calculating the lessor's royalty entitlement.

In principle, duties in relation to the allocation could arise from the express terms of a contract (the grantor of the interest might covenant to treat the grantee fairly, or in a non-discriminatory way, in negotiating the allocation principles of a pooling agreement). In practice they are more likely to arise from implied duties having their source either in the law of fiduciary duties or an implied contractual obligation of good faith. These questions have recently been the subject of extensive comment in Mesa. ${ }^{143}$ Prior to considering that case however, I shall begin with an analysis of typical lease clauses that bear upon this point.

\section{Production Allocation to the Lessor in Freehold Lease Pooling Clauses}

A review of oil and gas leases in use in Alberta reveals a consistent treatment of the allocation of production in pooling clauses. Without exception, the leases examined do two things. First, the lease grants the lessee, in more or less extensive terms, the right to enter into a pooling agreement. Typically, the lessee is accorded "the right and power" to pool. Secondly, the lease apportions production to the tract for the purposes of calculating the royalty on an areal basis. I am not aware of any lease that effects an allocation on a reserves basis. The CAPL lease form, for example, provides that the allocation shall "for all purposes, including the payment of royalty" be based upon the proportionate surface areal contribution of each tract. ${ }^{144}$ In the face of this explicit

144 See the CAPL lease clause, supra note 6; and the PanCanadian lease clause, supra note 74. 
language it is hard to imagine any court finding that allocation should occur on, for example, a reserves basis. ${ }^{145}$

\section{B. PRODUCTION ALLOCATION TO THE LESSOR UNDER COMPULSORY POOLING ORDERS}

A question may, however, arise as to what the result would be in the event that the tract owners were unable to negotiate a pooling agreement on an areal basis and, as a result, resorted to the compulsory pooling procedure under the Oil and Gas Conservation Act. ${ }^{146}$ Assume further that the Board ordered an allocation on other than an areal basis. Could a lessee find itself paying a royalty based upon an areal allocation when in fact it received a smaller share of production based upon a reserves formula? The answer must turn upon the actual language of the pooling order read in conjunction with ss. 9, 72 and 79 of the Oil and Gas Conservation Act.

In my view the collective effect of these sections is to override the allocation provided for in the lease. ${ }^{147}$ Section 72 provides the main authority for the Board to deal with compulsory pooling applications. Once the Board has satisfied itself that an application ought to be granted, subs. (4) requires that the order deal with a number of matters including "(c) the allocation to each tract of its share of production of oil or gas from the drilling spacing unit." Two subsequent provisions then purport to state the effect of the Board order, once it has been approved by the Lieutenant Governor-inCouncil. First, subs. (7)(b) states that where an order is made, "that portion of the production allocated to each tract, and only that portion, shall be deemed to have been produced from the tract." If that were not clear enough, s. 79 emphasizes that this deeming applies equally to a third party lessor and to the working interest parties in the DSU:

the portion of unit or pooled production allocated to each tract, and only that portion, shall, for all purposes be deemed to have been produced from that tract within the meaning of the terms and provisions of each lease or other contract applicable to that tract.

The effect of an inconsistency between a provision of the Act, or a Board order, and a contractual term is dealt with comprehensively by $\mathrm{s.} 9$ :

145 This proposition is surely confirmed by the decision of the Court of Appeal in Luscar, supra note 119.

146 Supra note 4, ss. $72-78$.

147 In Vandergriff, supra note 14, V, the holder of an overriding royalty interest in seven sections of land argued that its royalty should be calculated upon production from all the lands contained within a block according to the proportion that the seven sections bore to the entirety of the block rather than upon production from the one well on the seven sections. Virtue $J$. rejected that argument, commenting that a block order did not have the effect of changing the contractual obligations of parties (ibid. at 32). This was in contrast to the effect of compulsory pooling powers of the Board and also the unproclaimed compulsory unitization provisions (ibid. at 31-32). The judgment is not entirely satisfactory on this point, since Virtue $J$. appears to have confused compulsory unitization with compulsory pooling, but the general point is clear: unlike the position before him, Board orders dealing with both pooling and unitization (when proclaimed) may have the effect of changing private contractual relations. 


\section{A provision of:}

(a) this $A c t$,

(c) a declaration, order, direction of the Board pursuant to this $A c t$ in any matter over which the Board has jurisdiction,

(f) an order of the Lieutenant Governor in Council under this Act, overrides the terms and conditions of any contract or other arrangement conflicting with the provisions of the Act order....

In summary therefore, lease clauses invariably provide for the allocation of production on an areal basis, even where pooling has actually occurred on a reserves basis. However, where the Board makes a compulsory pooling order on a basis other than an areal basis, the terms of the order will override the allocation provided for in the lease.

\section{OTHER NON-PARTICIPATING INTERESTS}

With the benefit of this discussion of the lessor's royalty as background, we are now in a position to consider the position of the holder of the overriding royalty and the Mesa case. The applicable clause in the royalty agreement in Mesa was typical insofar as it accorded the working interest holder a broad discretion to enter into pooling agreements and, unlike the lease provisions, was silent as to whether an agreement should be on an areal or some other basis.

The Vendor grants the Purchaser the right to pool or unitize any portion of the Non-Producing Properties with any other lands and the Royalty in respect thereof shall be calculated on the production of petroleum substances allocated to the Non-Producing Properties included in such pool or unit. ${ }^{148}$

There were a number of issues between the parties including a dispute as to the payment of royalties on the production attributed to what may be called the section 4 lands. The facts have already been outlined above, but further details are required at this point.

Pursuant to the royalty agreement, Dome/Amoco took an assignment from Mesa of a 100 percent working interest in a Crown lease to the south half of section 4 . Subsequently, Maligne and TCPL (collectively "MT") each acquired a $12 \frac{1}{2} 2$ percent interest in the lease but the lease remained in Dome's name and Dome managed the interests on behalf of the MT partnership. Maligne's interest was transferred through a subsidiary of Dome to Conwest in 1983. In contemplation of this litigation, both TCPL and Maligne signed letters to the effect that Dome was entitled to act on behalf of the partnership and, if it had exceeded its authority in this regard in entering into a pooling agreement, the parties now approved of the arrangement. Dome was also the only party to a Crown lease to the north half of the section. 
In 1980 and 1981 Dome drilled a well on LSD 3 in the southwest quarter. The well was completed for production and commenced production as a gas well in June 1981. Between July 1984 and March 1990, correspondence ensued between Dome and Conwest as to the terms of a pooling agreement, but although a draft pooling agreement was in circulation as early as August 1984, a pooling agreement was not executed by Dome/Amoco and Conwest until 29 March 1990. After an initial period during which the Mesa royalty was paid upon 100 percent of production from the 3-4 well, Dome adjusted its accounts to provide that the royalty would be paid on 50 percent of production which assumed an areal allocation for the DSU.

At trial, considerable evidence was tendered to the effect that the boundary of the Basal Quartz reservoir in question cut through section 4 and that all the reserves lay under the south half. It was further alleged that this was known to Dome or ought to have been known to Dome at about the time the well commenced production. All of this was accepted in its essentials by Shannon J. He found that, "on the balance of probabilities, ... the producing reservoir underlies the south $1 / 2$ of section $4 .{ }^{149} \mathrm{He}$ further found that Dome proceeded with an area-based allocation for the purposes of calculating the royalty "even though it knew or must have suspected that the reservoir was located entirely or substantially under the south $1 / 2$ of the section." 150 But did those conclusions disclose a breach of a duty owed by Dome to Mesa, especially in light of the express language of the royalty clause? ${ }^{151}$ Shannon J. paused for a moment, but no longer:

That clause [he wrote] does not purport to dictate to Dome the method of pooling to be employed or the allocation of the revenues resulting therefrom. Therefore, in my view, Dome has the discretion to proceed as it sees fit but it is not an unfettered discretion, because it is obliged to act in good faith visà-vis the royalty holder. Such a term exists by implication. ${ }^{152}$

With that conclusion established, Shannon J. proceeded to consider the applicability of two alternative legal doctrines that might provide the source of a duty: the law of fiduciary duties and the implied contractual duty of good faith. I shall consider each in turn.

is! The precursor of the Mesa case is Vandergrift, supra note 14 (see supra note 147 for a brief recitation of the facts) which dealt with the duty owed to a royalty holder by a working interest owner in entering into a production allocation agreement and in the subsequent operation of the ensuing block. $\mathrm{V}$ alleged among other things that its royalty should be calculated upon the basis of the areal contribution of the lands in which it held the royalty to the entire block (supra note 14 at 22). From the report however, it appears as if argument focused on the actual operation of the lands and on the effect of the Board's block. The plaintiffs do not appear to have argued that the defendants had breached their duty to $\mathrm{V}$ in the negotiation and execution of the PAA. Nevertheless, it is clear that Virtue J. considered the plaintiffs to be in a weak (and vulnerable) legal position. He commented that "[o]ne of the fundamental difficulties which the plaintiffs face is that they are unable to show that they have any right, contractual or otherwise, to control the manner in which the owners of the lease arrange the production of natural gas from their lands." (ibid. at 32). 


\section{A. FIDUCIARY DUTIES}

During the last decade we have witnessed the steady intrusion of fiduciary and trust law concepts into oil and gas contractual arrangements. ${ }^{153}$ Plaintiffs have eagerly seized the opportunities thus presented. In particular, the fiduciary analysis has been used in order to: (1) supplement the duties owed under the terms of the relevant contract; (2) to avoid limitations problems associated with the failure of Alberta courts

The main cases are:

(1) Midcon Oil and Gas Lid. v. New British Dominion Oil Company, [1958] S.C.R. 314. The majority held that the duty owed by an operator to a joint operator did not extend to marketing and sale of minerals produced from the jointly owned property; there was however a duty of good faith but no breach of that duty on the facts. The Court of Appeal of Alberta (1957), 21 W.W.R. 228 at 234-38 held that there was a fiduciary relationship in relation to the marketing of the gas. However, in its view, there was no breach of a duty because the benefits of the promotion of the fertilizer company flowed from other actions of the defendant than its ownership of the gas.

(2) Manning v. Calvan Consolidated Oil and Gas Company Limited and Imperial Oil Limited (No. 2) (3 August 1960), (Alta. S.C.) [unreported], full text reproduced in Canadian Oil and Gas, supra note 3. The Court held it was a breach of trust or of a fiduciary obligation for an operator to negotiate a package farmout agreement with a third party that did not deal evenhandedly with the interest of a joint operator.

(3) Great Northern Petroleums \& Mines v. Merland Explorations Limited and Canada Northwest Land Limiled (1983), 25 Alta. L.R. (2d) 67, (Q.B.), affd (1985), 36 Alta. L.R. (2d) 97 (C.A.), held that although an operator owes fiduciary duties to a joint operator, where a farmout agreement imposed AMI obligations, it was impossible to imply a fiduciary duty in relation to the acquisition of other lands because such lands were beyond the scope of the joint enterprise.

(4) Bank of Nova Scotia v. Société General (Canada), [1988] 4 W.W.R. 232 (Alta. C.A.) [hereinafter Société General], held that the operator under the CAPL 1981 agreement is an express trustee for the joint operator for AFE monies and monies received from the sale of production and held in a commingled account.

(5) Luscar, supra note 119. The operator owed a fiduciary duty to the joint operator in the exercise or implementation of an AMI clause. The operator was also an express trustee for the joint operator (ibid. at 76); on appeal, ibid., the Court of Appeal reversed the decision of the trial court. The Court affirmed that an operator may owe fiduciary obligations but not all of its obligations were fiduciary in nature. Unfortunately, the Court failed to deal comprehensively with many of the earlier Q.B. decisions referred to in this note and also failed to discuss the decision of the S.C.C. in Hodgkinson v. Simms, [1994] 9 W.W.R. 609 which had been handed down on September 30, 1994. At a very abstract level, Hodgkinson and Luscar are inconsistent. In each case, the alleged fiduciary duty covered the same ground that was the subject of either an express term of the contract (Luscar) or an implied term (Hodgkinson). Yet, in Hodgkinson the majority of the Court found that there was a breach of the fiduciary duty, while in Luscar the Court held that it was impossible to find an additional fiduciary duty in the presence of an entirety clause, and where the alleged duty covers the self-same ground as the contract. It may be possible to reconcile the cases on the basis that Hodgkinson deals with a personal advisory relationship in which it was reasonable for the client to form the opinion that the advisor would put aside his personal interest and act exclusively in the interests of the client, all in a manner that went beyond the terms of the contract.

(6) Erehwon Exploration Lid. v. Northstar Energy Corp. (1993), 108 D.L.R. (4th) 709 (Q.B.) [hereinafter Erehwon]. In many of its functions under the 1981 CAPL the operator owes fiduciary duties to the joint operator specifically in: (a) the exercise or implementation of AMI contractual rights; (b) self dealing without advance disclosure and consent in relation to well drilling contracts and well operating contracts; and (c) committing joint account monies and determining appropriate deductions for processing charges for royalties. However, there was no breach of a fiduciary duty where the operator purchased gas for its own account as authorized by the terms of the CAPL. 
to apply the discoverability rule to causes of action in contracts ${ }^{154}$ and to obtain other limitations advantages; and (3) to assist in obtaining the benefit of equitable proprietary remedies so as to obtain some priority vis-à-vis general creditors. ${ }^{155}$ The analysis and reconciliation of these cases is properly the subject of another article, and urgently requires the attention of the Alberta Court of Appeal or the Supreme Court of Canada. Suffice it to say for present purposes that some of the cases are problematic insofar as courts have been willing to find not just a fiduciary relationship but also an express trust on very thin evidence; ${ }^{156}$ still other cases are difficult to reconcile. In my view this last is particularly true of the Mesa case as I hope to demonstrate in the next paragraphs.

Shannon J. found that "the terms of the agreement between Mesa and Dome, by implication, do not create a fiduciary relationship and are not reasonably susceptible to that interpretation." ${ }^{157}$ Shannon J. gave two primary reasons for this conclusion. The first turned upon the majority opinion in $L A C$ v. Corona, ${ }^{158}$ and the second turned upon his interpretation of the Société General case.

Shannon J. relied upon $L A C$ for the conclusion that a court should not readily find a fiduciary relationship in a situation, such as the case at bar, where there were two commercial companies acting at arm's length, each with access to legal and technical advice. This was not a case of inequality of bargaining power. ${ }^{159}$ One can hardly fault this reasoning as the starting point for an analysis of the relationship between the parties but it is surely nothing more than that, a starting point, and one needs to probe a little more deeply.

Shannon J. began his analysis by acknowledging that the Supreme Court in $L A C$ had adopted a three-step test for determining the existence of a fiduciary duty, namely:

(1) the defendant [fiduciary] has scope for the exercise of some discretion or power;

(2) the defendant [fiduciary] can unilaterally exercise that power or discretion so as to affect the plaintiffs [beneficiary's] legal or practical interests;

Luscar Lid. v. Pembina Resources Lid. (1992), 131 A.R. 79 (C.A.); 98956 Investments Lid. v. Fidelity Trust Co. (1989), 89 A.R. 151 (C.A.).

See e.g. Société General, supra note 153; and Canadian Imperial Bank of Commerce v. Twin Richfield Oils Lid. (1992), 88 D.L.R (4th) 596 (Alta. Q.B.) (Case comment by Klinck at (19921993) 8 B.F.L.R. 393).

See e.g. Société General, ibid. at 237-38; and CIBC v. Twin Richfields, ibid. at 607-08. The trial judge in Luscar, supra note 119 at 76, also found an express trust in relation to the lands acquired in breach of the AMI clause. The Court of Appeal, ibid. at 343-47 (C.A.), in my view correctly, quashed this idea on the basis that there was no certainty of intention.

Supra note 134 at 217 (Q.B.). See also at 216: "the plaintiff's claim that the defendant owed it fiduciary duties is not supportable from a reading of the express terms of the various agreements, nor can they be implied...."

LAC Minerals v. International Corona Resources (1989), 61 D.L.R. (4th) 14 (S.C.C.) [hereinafter $L A C]$.

Supra note 134 at 215 (Q.B.). 
the plaintiff [beneficiary] is peculiarly vulnerable to or at the mercy of the defendant [fiduciary] exercising [holding the discretion or] the power. ${ }^{160}$

As is well known, the three "criteria" were first identified as hallmarks of the fiduciary relationship by Wilson J. in her dissenting judgment in Frame v. Smith, ${ }^{161}$ but have since been adopted by the Supreme Court in several recent fiduciary relationship cases. ${ }^{162}$ Applying the hallmarks here, and drawing upon Sopinka J.'s judgment in $L A C$, Shannon J. stated:

The court went on to say [in $L A C$ ] that if the plaintiff had only alleged a breach of fiduciary duty [and not also a breach of the duty of confidence], that duty would not have been found to have arisen on those facts. That is because the plaintiff there (as in this case), could not demonstrate that an element of dependency existed between plaintiff and defendant so as to show the plaintiff as "... peculiarly vulnerable to the alleged fiduciary holding the discretion...". Similarly here, the plaintiff cannot overcome the absence of the element of dependency, which is essential for a finding of a fiduciary relationship. ${ }^{163}$

This comparison between $L A C$ and the facts of Mesa ignores one fundamental difference between the two cases. $L A C$ dealt with a pre-contractual relations setting; it was concerned with the duties owed by parties during attempts to negotiate a joint venture. In Mesa we are concerned with how broad discretionary powers are exercised under the contract. The question is therefore not one of vulnerability at the time the contract was negotiated, as in $L A C$, but rather whether one party is peculiarly vulnerable to the exercise of powers created by the contract.

This distinction has been recognized in several subsequent oil and gas contracts cases. In Luscar, ${ }^{164}$ Egbert J. held that a joint operator was peculiarly vulnerable to the exercise of powers by an operator in the context of an area of mutual interest

Ibid. at 214. The bracketed language is from the original judgment of Wilson J. (dissenting) in Frame v. Smith (1987), 42 D.L.R. (4th) 81 (S.C.C.).

Ibid. Wilson J. described the three elements as "general characteristics" of relationships in which a fiduciary obligation had been imposed.

See $L A C$, supra note 158, Sopinka and La Forest JJ.; Canson Enterprises Lid. v. Boughton \& Co. (1991), 85 D.L.R. (4th) 129, McLachlin J. (Lamer C.J.C. and L'Heureux-Dubé J. concurring); Norberg v. Wynrib (1992), 92 D.L.R. (4th) 449 at 488, McLachlin J. (L'Heureux-Dubé J. concurring); and Hodgkinson v. Simms, supra note 153 at 628, La Forest J. At this point in this article I am attempting to critique Shannon J.'s judgment on its own terms; hence the emphasis on vulnerability. A broader critique would also ask whether the reliance on vulnerability as the hallmark, or as indeed the leading hallmark of a fiduciary relationship, is accurate. I am persuaded by the reasoning of Paul Finn that it is more productive to focus on the fiduciary's duty of loyalty and therefore to ask whether, in all the circumstances (including the contractual matrix between the parties), it was reasonable for the one party to conclude that the other would put aside its self interest and act in the interests of the other (or, in the case of a partnership or joint venture, the interests of the joint venture rather than its self interest). Given the focus of the present article, the point cannot be pursued here, but see P. Finn, "Contract and the Fiduciary Principle" (1989) 12 U.N.S.W.L.J. 76. This approach is supported by La Forest J. in Hodgkinson, supra note 153 at 629. See also Nocton v. Ld Ashburton, [1914] A.C. 932 especially at 971-72, Lord Shaw. 
clause. Although the Court of Appeal reversed Egbert J., it did so on the basis that the plaintiffs were not in fact vulnerable. The AMI clause bound the defendants and plaintiffs equally. Each of the plaintiffs was a sophisticated business entity and each had a highly developed land department. ${ }^{165}$ Furthermore, an AMI clause was seen by the Court as an example of a specific clause designed to provide a contractual entitlement for the parties thereby reducing any apparent vulnerability. That is clearly different from a clause such as that operating in the Mesa case which accorded Dome/Amoco such a broad discretion in the way in which it dealt with the subject lands. The clause could not be interpreted as having reduced the vulnerability of the royalty holder. Vulnerability to the exercise of a discretionary power accorded by the contract was also identified by Hunt J. in Erehwon where she found that the joint operator was peculiarly vulnerable to the operator under the terms of the CAPL operating procedure in a variety of fact patterns. ${ }^{166}$

In neither Luscar nor Erehwon was there a finding that the joint operator was vulnerable in the negotiation of the contract. ${ }^{167}$ Indeed, that would hardly make sense, since today's joint operator may, through the operator replacement provisions of the agreement, ${ }^{168}$ become tomorrow's operator. ${ }^{169}$ Instead, vulnerability arises from the allocation of broad discretionary powers by the terms of the contract itself. In my view, if these cases permit one to conclude, in the context of the joint operating agreement, that the joint operator may be vulnerable to the operator, ${ }^{170}$ this must even more clearly be the case between the holder of the passive royalty interest and the holder of the working interest.

As is well known, the operating procedure attempts to balance the operator's need for some operational flexibility with the joint operator's wish to control the limits of its financial exposure. Accordingly, protections for the joint operator are built into the agreement including provisions dealing with the replacement of the operator, ${ }^{171}$ the

Supra note 119 at 334 (C.A.).

Supra note 153.

This was certainly the case in Luscar. In Erehwon, Hunt J. did conclude that the plaintiff had "considerably less bargaining strength" than the defendant but at the same time acknowledged that each had access to legal and technical advice (ibid. at 714-15). There was no finding of vulnerability.

CAPL, article II; although in practice it may be difficult to obtain the assistance of the courts in the removal of an operator. See Norcen Energy Resources Ltd. v. Oakwood Petroleums Lid. (1988), 63 Alta. L.R. (2d) 361 (Q.B.); Tri-Star Resources Lid. v. J.C. International Petroleum Ltd. (1986), 48 Alta. L.R. (2d) 355 (Q.B.); Rimoil Corp. v. Hexagon Gas Lid. (5 May 1989), (Alta. Q.B.) [unreported], digested in Canadian Oil and Gas, supra note 3, Digest No. 328; Gulf Canada Resources Lid. v. Pembina Resources Lid. (1994), 152 A.R. 74 (Q.B.).

Furthermore, the focus on vulnerability in entering into the contract is arguably not to the point where the contract is a standard form designed to balance interests.

Although the Court of Appeal in Luscar is clearly more demanding than was Egbert J. in determining whether or not there is vulnerability on the part of the joint operator, it certainly does not preclude the possibility.

CAPL 1981 at article II. 
AFE mechanism ${ }^{172}$ and articles requiring the operator to provide information to the joint operators. ${ }^{173}$ Generally, a royalty holder can claim no such protection under the terms of its contract. By and large this is a reflection of the fact that the royalty holder is often less exposed; it may never have put up risk capital. Thus the up-front financial risk of a royalty holder may be lower than that of a joint operator but the vulnerability to the exercise of unilateral discretionary powers by the working interest owner will often be greater in relation to matters such as pooling and production allocation agreements.

Shannon J.'s second reason for rejecting the existence of a fiduciary duty turned upon his analysis (and distinguishing) of the Sociéte General $l^{174}$ case. I have no quarrel with the general claim that the two cases are distinguishable; after all, the Court in Société General actually found that monies received by the operator were subject to an express trust. However, the grounds upon which Shannon J. rests his analysis are of interest insofar as they relate to the $L A C$-based discussion on vulnerability. Shannon J. argued that the Court was able to find a fiduciary relationship in Société General because of the contractual provisions in the CAPL agreement requiring that the joint operators be kept informed and consent to operations through the AFE mechanism. ${ }^{175}$ By contrast, the very breadth of discretion accorded to Dome/Amoco in the present case made it impossible to imply a fiduciary relationship. ${ }^{176}$ No reason is given for this conclusion. By implication, Shannon $J$. is suggesting that if the parties negotiate a contract that accords one party a broad discretion in its execution or implementation, it is impossible to imply further fiduciary duties, yet it is precisely in such a situation that the other party is most vulnerable. Furthermore, it may be quite impractical to negotiate a contract at a higher level of detail thereby avoiding the need to confer broad discretionary powers.

Taken together, the reasoning on these two points is perverse. On the one hand, Shannon J. ignores the evidence of vulnerability in the implementation and operation of the contract (as opposed to its negotiation) and finds no fiduciary duty; and yet on the other hand, that same evidence of vulnerability, framed in terms of Mesa being at the mercy of Dome's exercise of its broad discretionary powers, is relied upon to make it impossible to imply further duties.

I prefer the reasoning of Hunt J. in Erehwon and, to the extent that vulnerability can actually be established, that of Egbert J. in Luscar. These two discussions recognize the reality that oil and gas contracts are, of necessity, of long duration and cannot possibly anticipate all future scenarios. The discretionary power of one party over another is an essential element of their successful operation. But it does not follow from this that the

Ibid. at para. 301. Furthermore, although public policy suggests that an operator should be able to rely upon an AFE once executed by the joint operator, there are signs that the courts will use the fiduciary analysis to go behind the executed AFE: see Erehwon, supra note 153; and Prairie Pacific Energy Corp. v. Scurry-Rainbow Oil Lid. (1994), 52 C.P.R. (3d) 289 (Alta. Q.B.). 
vulnerable party has thereby renounced all thought of judicial supervision of the discretionary powers. Consequently, based on these two cases, I would argue that it is still open to the holder of a royalty interest to argue that it is owed fiduciary duties in the negotiation of the allocation principle of pooling agreements. The point was not considered by the Court of Appeal in Mesa which focused its attention on the duty of good faith. Neither do I think that the point loses its force as a result of the Court of Appeal's decision in Luscar. That decision is primarily concerned with the situation in which there is a contractual obligation that is on all fours with the proposed fiduciary obligation. The fact situation of Mesa is readily distinguishable insofar as the contract was silent on an appropriate allocation formula in the event of pooling. The reasoning of the Court of Appeal in Luscar will be applicable to the typical pooling clause contained in freehold leases which prescribes an acreage-based allocation, but I have already acknowledged that the precise language of that type of clause makes it impossible to read in further obligations of a fiduciary nature.

\section{B. THE DUTY OF GOOD FAITH}

The other source of an additional duty to be imposed upon the working interest holder considered by Shannon J. was a proposed implied contractual obligation of good faith. ${ }^{177}$ On this argument the plaintiffs had considerably more success. The argument will rarely be as attractive to a plaintiff as the fiduciary route because it does not have the advantage of avoiding limitations problems and it may not be as easy for a plaintiff to seek an equitable proprietary remedy. ${ }^{178}$

In reaching the conclusion that Dome/Amoco had breached its implied obligation of good faith, Shannon J. relied very heavily upon the decision of Kelly J. of the Nova Scotia Supreme Court in Gateway Realty Ltd. v. Arton Holdings Ltd. ${ }^{179}$ That case, he suggested, was authority for the proposition that there was "an obligation on parties to a contract to act in good faith." The duty "limits the exercise of discretion conferred on parties by an agreement." In particular, a party would be in breach when it acted "in a manner that substantially nullifies the contractual objectives or causes significant harm to the other, contrary to the original purposes or expectations of the parties." 180 In the present case, the breach lay in the fact that Dome went ahead with the areal pooling notwithstanding the knowledge of its employees ${ }^{181}$ as to the distribution of reserves. What should they have done?

Shannon J. also considered (ibid. at 217) another potential source of additional duties, namely the "reasonable, prudent operator" standard, before discarding it on the ground that it would rarely, if ever, be necessary to distinguish between it and the good faith standard. largely decoupled the link between equitable proprietary remedies and the existence of a fiduciary relationship. See especially the judgment of La Forest J. in $L A C$, supra note 158 at 29-32, 44-52. (1991), 106 N.S.R. (2d) 180, afrd (1992), 112 N.S.R. (2d) 180 (C.A.) [hereinafter Gateway Realty].

181 See the findings of fact referred to above, accompanying text to supra note 146 ; ibid. at 221. 
I find that the knowledge that they possessed at the time of pooling as to the most likely reservoir dimensions and geographical markers should have alerted them to their good faith obligation to consult with Mesa. Only then would Mesa have had a reasonable opportunity to reach an equitable agreement with Dome, or alternately, urge that an application be made to the ERCB to resolve the matter.

The failure to proceed in that manner constituted a breach of the implied term of the contract obliging Dome to act in good faith. ${ }^{182}$

As stated here, the obligation was not an obligation to pool on a reserves basis, but was an obligation to consult. The obligation goes beyond mere consultation however, since Shannon J. clearly suggests that if an "equitable solution"183 could not be reached, resort should be had to the Board's compulsory pooling procedures. It is not entirely clear to me that the Board would be obliged to adjudicate on such an application, even taking into account the Blue Range decision discussed above. ${ }^{184}$ Dome had an ownership interest throughout the DSU. The presence of other working interest holders within the different tracts might bring the application within the $A c t,{ }^{185}$ if one of those working interest parties wished to take issue with Dome's proposed allocation. But what if they did not? Presumably, Maligne and TCPL were actually quite content with Dome's allocation!

Reference to the possible use of the Board's compulsory pooling jurisdiction both confuses and clarifies the issue. On the one hand, it adds clarity and certainty to the uncertain concept of good faith by providing a standard against which to measure Dome's conduct: i.e. whether allocation on an areal basis was "inequitable" as that term is used in the $A c t .{ }^{186}$ On the other hand, it confuses insofar as it makes it more

Ibid.

The reference to an "equitable" solution must be a reference back to s. 72(4)(c) of the Oil and Gas Conservation Act, supra note 4 , instructing the Board in making a compulsory pooling order to allocate production "on an areal basis unless it can be shown to the Board that that basis is inequitable."

See supra note 45.

Suppose, further, that Dome held each lease to the north and south halves as to a 100 percent undivided interest. In that case it is hard to see that the Board would have any jurisdiction. On appeal, the Court of Appeal took a different and broader view of the Board's jurisdiction. It concluded that the Board would have jurisdiction, but on different grounds. In particular, Kerans J.A. seems to have been of the view that, if the circumstances had been explained, the Board would have adjudicated on a dispute between a working interest owner and a royalty interest (supra note 134 at 195 (C.A.)). No supporting reasoning was offered for this conclusion and in my view it is mistaken. The Board's jurisdiction is limited to disputes between owners of tracts (Oil and Gas Conservation Act, supra note 4, s. 72). An owner is defined (ibid., s. 70(a)) as including the person who has the right or an interest in the right "to drill for, produce and dispose of any oil or gas from the tract." While this definition is inclusive rather than exhaustive, the owner must still be an owner "of a tract." Although there is some circularity in the definitions of the two terms, it would be a stretch to describe a royalty holder as not merely an owner but also as an "owner of a tract." Certainly, if the Board were to accept jurisdiction it would have to considerably extend its current practice. The comments of both courts on the jurisdiction of the Board are of course obiter.

"Equity" as used in the $A c t$ does not have its ordinary Chancery usage but is keyed to the principle that a mineral owner should have the opportunity to produce the reserves underlying her land. 
difficult to identify the precise content of the duty. Is the duty really just a duty to consult, or is it (to use some of the other tests suggested by Shannon J.) a duty to effect an allocation that does not substantially nullify the contractual objectives of the parties, or cause Mesa significant harm, or which is not "contrary to the original purposes or expectations of the parties"?

The precise scope of the duty, as well as its source, continued to trouble the Court on appeal. Thus, at the commencement of his judgment, we find Kerans J.A. stating that the trial judge had found "that the agreement obliged Amoco to pool on the basis of the actual location of the gas reservoir...." ${ }^{187}$ Later, the duty appears merely as a duty to advise the royalty owner in situations in which there might be a judgment call involved in the decision to pool on an areal rather than a reserves basis. ${ }^{188}$

On appeal Amoco had two main arguments. First, Amoco argued that the duty of good faith was, in effect, a duty not to act in bad faith or from bad motives. Hence in order to establish a breach, it was said, one would have to inquire into the state of mind of the party alleged to have breached and ascertain that the exercise of the discretionary power under the contract was motivated by bad faith reasons. The test therefore was subjective and not an objective test resembling that of the duty of care. That submission was rejected by both the trial judge and the Court of Appeal on the ground that it established too high a threshold. Kerans J.A. noted with approval the trial judge's summation of the Gateway Realty case quoted above. ${ }^{189}$ But, having reached that conclusion, Kerans J.A. in effect walked away from this analysis, ${ }^{190}$ preferring to found Amoco's duty in the proper interpretation of the agreement as informed by "the traditions and practices of the ... industry."191 The difference in approach is made quite clear in the following paragraph of his judgment:

In any event, it is not necessary for this case that I go further into this difficult area [i.e. of the duty of good faith]. This is because this case tums on a rule founded in the agreement of the parties, not in the law. In my view, as a matter of fact, this contract created certain expectations between the parties about its meaning, and about performance standards. If those expectations are reasonable, they should be enforced because that is what the parties had in mind. They are reasonable if they were shared. Of course, those expectations must also, to be reasonable, be consistent with the express terms agreed upon. This contract should be performed in accordance with the reasonable expectations created by it. ${ }^{192}$

Supra note 134 at 190 (C.A.).

Ibid. at 192.

See supra note 179.

There are several indications of this in the judgment, supra note 134 at 191 (C.A.). Kerans J.A. ventured: "[m]y only hesitation is whether one need, in this discussion, employ the term 'good faith.'" Later he states that "[a] general obligation expressed in terms of good faith is not an obvious part of contract law in England and Canada..." and then he went on to consider "[t]he argument the other way is that 'good faith' is too vague a term." (ibid. at 192).

Ibid. at 192.

Ibid. 
The traditions and practices of the industry to be considered included, in Kerans J.A.'s view, a practice of pooling on a reserves basis if there was a significant variance between the boundaries of the reservoir and those of the corresponding surface parcels. The confirmation for this practice was established by applications to the Board for compulsory pooling orders where an areal allocation would be inequitable. Further support for the practice could be drawn from Amoco's own witnesses who acknowledged that reserves-based pooling, although rare, did happen even in 1981 when Dome made the decision to pool on an areal basis. ${ }^{193}$ But if that was the practice, what was the expectation of Dome/Amoco and Mesa at the time they made their agreement? It was that:

at a minimum ... Amoco would consider both areal and reserves-based pooling, and follow whichever route the facts justified. The expectation might also have been that the operator would advise the holder of the gross royalty of all the facts of the matter in a case where the decision was anything but completely straightforward and, as here, there happened to be a conflict of interest. ${ }^{194}$

This quotation reveals continuing imprecision as to the nature of the duty cast upon Dome/Amoco. Later, Kerans J.A. suggested that the breach consisted of a failure to consider the matter of reserves-based pooling, or a failure to take further steps. ${ }^{195}$ In other words, Dome had sufficient information before it to realize that there was a potential problem; it failed to do anything and therein lay the breach.

Framing the breach this way led directly to the second ground of appeal which was that the trial judge had incorrectly assessed damages by "failing to place the complaining party in no better position than it would have enjoyed had there been no breach."196 To put the point more colloquially: even if Dome had "breached its duty," it was not clear, on the balance of probabilities, that Mesa would have been in a better position had there been no breach. This of course requires one to identify the breach with some precision.

The first argument was that had Mesa been consulted in 1981, it would have consented to areal pooling. Secondly, Amoco argued that had Dome made an application to the Board in 1981 the Board would, given the uncertainties as to the geological evidence, have ordered areal pooling. In effect, Kerans J.A. ruled that both of these arguments had been pre-empted by the trial judge who had made no errors justifying correction by the Court. Justice Kerans does not seem to have dealt directly with the first argument. Instead he referred to a finding of the trial judge to the effect that had Mesa been consulted it would have had the opportunity to reach an equitable agreement or urge an application to the Board. ${ }^{197}$ This finding, although valuable, does not seem to meet Mesa's argument. The second question was disposed of more convincingly by Kerans J.A.'s conclusion that the trial judge had indeed asked himself

197 The relevant passage is quoted in the accompanying text to supra note 182. 
the same question, and adopted the same burden of proof as would the Board had it been seized of the matter, and there was no evidence to show that the issue would have been decided differently in 1981 from $1991 .{ }^{198}$

\section{NON-PARTICIPATING INTERESTS - SUMMARY}

In the last two parts of the article, I have attempted to ascertain the scope and extent of the duties owed by the working interest owner to the owners of non-participating interests when the working interest owner enters into a pooling agreement. Analysis of both standard form leases and documents creating non-participating interests reveal that they typically accord a broad discretion to the working interest owner to pool. The lease provisions go further and mandate a production allocation for royalty calculation purposes on an areal basis. Given the specificity of this language it is impossible to imply a more onerous duty on the lessee to pool on a different basis where an areal pooling would result in an inequity for the lessor. However, the lessee may protect its own interest by applying for a compulsory pooling order and seeking to pool on a reserves basis where appropriate. The resulting decision of the Board will bind the lessor. The lessor may therefore be protected by such an application, but only if the lessee and lessor happen to share the same interest in a reserves-based pooling. Where their interests differ it would appear that the lessor is left without a remedy. ${ }^{199}$ Their interests are most likely to diverge where the lessee holds a working interest in more than one tract in the DSU. Where the lessee has only a single tract, one could expect the interest of the lessee and lessor to be convergent.

Where the document according the power to pool is silent on the method of allocation, the working interest owner may owe additional duties to the owner of the non-participating interest. Three possibilities have been canvassed. The first possibility is the fiduciary duty. This approach was rejected by Shannon J. in Mesa, but I have suggested that this conclusion may be open to question. Secondly, the duty may be based upon an implied contractual duty of good faith. Although this was the basis of Shannon J.'s decision at trial in Mesa, it does not seem to have received much support on appeal. Instead, the Court of Appeal seems to have articulated a third basis for the duty, to wit, that there is an industry practice or custom that it is an implied term of every contract creating a non-participating interest that, where a serious inequity would be caused for the holder of that interest by entering into a pooling agreement on an areal basis rather than a reserves basis, there is a duty to consult the party affected and perhaps, a duty to pool on a reserves basis at the request of that party, or to apply to the Board to have it determine an equitable allocation formula.

While this third source of the duty may offer the advantage of greater precision than the vague concept of "good faith," it is questionable whether the conclusion is language requiring an areal pooling. The best analogy on the decided cases here is with Hunt J.'s decision in Erehwon on the gas marketing issue, supra note 153 at 754-60, and the decision of the Court of Appeal in Luscar, supra note 119. 
adequately supported by the evidence. Most cases suggest that the threshold for establishing the existence of a custom is quite high. ${ }^{200}$ Yet in the present case, a customary basis for the duty does not even seem to have been argued at trial, nor supported by a bevy of expert testimony. Instead, Kerans J.A. was forced to find support for a custom in the industry based upon the evidence that, in some circumstances, some parties apply to the ERCB for a compulsory pooling order. There was no evidence that such parties made an application out of a sense of obligation, and not simply because they were motivated by pure economic self-interest.

\section{LAND TITLES}

The final issue for consideration is that of land titles. Do pooling agreements raise land titles issues of which the practitioner should be aware? It is well established that unitization agreements pose specific land titles problems and, for present purposes, the question must be whether those problems are also posed by pooling agreements.

Land titles problems arise from unitization agreements because unitization agreements generally constitute an amendment to the lease. ${ }^{201}$ Two propositions follow. First, in order to bind a third party, the unitization agreement needs to be noted on title either by way of caveat or by means of a memorandum pursuant to s. 53 of the Land Titles Act. ${ }^{202}$ Secondly, continuation of a lease by a unitization will not bind a third party (such as a top-lessee) that is an intervening caveator between the original lease caveat and the subsequent unitization caveat or $\mathrm{s}$. 53 memorandum. The direct authority for this second proposition is Esso Resources ${ }^{203}$ but that case, in turn, is an application of the earlier decision in the Potapchuk ${ }^{204}$ case, in which it was established that an amendment to a lease to include a pooling clause designed to avoid the infirmities disclosed in Gunderson could not bind an intervening top-lessee that had caveated its interest.

That allows us to sharpen the focus of our present inquiry - does the execution of a pooling agreement constitute an amendment to the typical lease such as to require separate protection on the certificate of title? Such authority as there is suggests that a pooling agreement does not require separate protection provided that the pooling is one that is contemplated by the original lease. This was the conclusion of Rooke $J$. in

The usage must be "notorious, certain and reasonable": Chitty on Contracts, 26th ed. (London: Sweet \& Maxwell, 1989) at para. 917. Esso Resources, supra note 74; World Wide Oil and Gas (Western) Lid. v. Canadian Superior Oil Ltd. (1990), 65 D.L.R. (4th) 417 (Alta. C.A.) [hereinafter World Wide Oil and Gas]. a s. 53 memorandum. This may pose problems where only part of the lease in question is included on the unitization. Following World Wide Oil and Gas, ibid., this may not be problematic where the entire lease area is included within a single certificate of title. However, if the lease property is held under more than one title, the lessee will need to caveat all the titles that are continued by the unitization if those titles have not been protected by a s. 53 memorandum: Esso Resources, ibid. 
the Panco case ${ }^{205}$ and it seems justifiable provided that the original caveat protecting the lease is sufficiently broad to contemplate extension of the lease by operations on pooled lands. This should not pose much difficulty given the generous interpretation of the effect of a caveat that is demonstrated by the Zeller's (Western) ${ }^{206}$ and World Wide Oil and $\mathrm{Gas}^{207}$ decisions of the Alberta Court of Appeal. ${ }^{208}$ In the unusual case where a pooling agreement purports to amend the lease, ${ }^{209}$ it will require a separate caveat and presumably also execution by the lessor. This last point was made by the Court of Appeal in Durish v. White Resources Management Ltd. ${ }^{210}$

Finally, it should be noted that these conclusions need modifying in situations where the pooling has effected a cross-conveyance. While the original lessee's interest no doubt continues to be protected by its original caveat, it would be well advised to caveat its new interest in the other tracts in the balance of the DSU. ${ }^{211}$

\section{CONCLUSIONS}

The pooling agreement has evolved as a mixed public and private law response to the spacing rules of modern oil and gas conservation legislation, and the problems posed by common property resources. A major function of the agreement is to permit the drilling of a well within the drilling spacing unit and to provide for an allocation of production amongst the tract owners. For the most part, the owner of the corporeal estate, the working interest owner, and indeed the holder of a non-participating interest have a shared interest in facilitating the negotiation of pooling agreements. There is also a public interest in facilitating pooling in order to encourage the drilling of wells that meet the conservation rules. These shared interests in pooling would suggest that the courts should insist upon only a minimum of formality in looking for evidence of a pooling. To some extent, this approach is borne out by the case law, especially the recent decisions in Panco and Mesa. It is less apparent in the earlier cases of Gibbard and Gas Initiatives. The case law also shows that the courts have insisted upon an inclusive approach in relation to pooling. Thus, Gibbard tells us that the only valid pooling is a pooling that embraces all the tracts within the DSU. Panco goes even further and, inferentially, requires that all the working interest holders in each tract of the DSU agree to the pooling before freehold leases can be extended beyond their primary term. While the former proposition seems to follow from the conservation rules, it is not clear that conservation rules or the well licence provisions demand the second conclusion.

Supra note 76 at 370.

Calford Properties Lid. v. Zeller's (Western) Ltd., [1972] 5 W.W.R. 714 (Alta. C.A.) [hereinafter Zeller's (Western)].

Supra note 201.

Although this line of cases seems dominant, a much more technical approach was taken by the Court, sitting as a panel of five, in Holt Renfrew Co. v. Henry Singer Lid., [1982] 4 W.W.R. 481 (Alta. C.A.).

See e.g. the facts of Foralla Resources, supra note 19.

(1988), 63 Alta. L.R. (2d) 265 (C.A.).

The broad definition of "unit agreement" in s. 53 of the Land Tilles Act, suggests that it would be possible to file a s. 53 memorandum instead of a caveat. 
A strict approach to pooling is no doubt appropriate in those situations in which the interests identified above diverge. These include the circumstances in which the working interest owner needs to prove the existence of a pooling agreement in order to extend the lease. Divergent interests in an allocation principle might also suggest a strict approach when determining whether a pooling agreement had been finalized but it seems more appropriate to focus attention on the allocation principle itself. This indeed was the approach taken in Mesa. Certainly the Court in Mesa had the opportunity to resolve the case by finding that an informal internal pooling was not such a pooling as could bind a non-participating interest. Instead the Court attacked the allocation principle much more directly, as it was able to do in the absence of a provision in the head agreement mandating a particular allocation principle. The result in Mesa certainly accords with an intuitive sense of justice but, for the reasons given above, the fiduciary analysis seems preferable to that of either the trial Court's duty of good faith reasoning, or the appellate Court's reliance on an industry custom.

I shall conclude by drawing together two suggestions for statutory or regulatory reform that I have alluded to in the course of the article. The first arises directly from the Mesa decision. Mesa stands as authority for the proposition that where the head agreement is silent on the principle of allocation, the working interest owner must consult with the holder of the non-participating interest before finalizing a pooling arrangement in any situation in which an areal allocation might cause inequity because of the distribution of reserves in the DSU. But will that fulfil the duties owed by the working interest holder, or are there other obligations? Where there is an express provision to the effect that the working interest holder is entitled to deal with the property as it sees fit, it surely goes too far to suggest on the basis of either custom, a duty of good faith or a fiduciary duty, that the working interest holder must obtain the consent of the royalty holder to the proposed pooling. But short of that, how else is the working interest holder to discharge its obligation? Is mere consultation enough? One would hope not. The duty must extend to an obligation to propose an allocation principle that is equitable within the meaning of the Oil and Gas Conservation Act. But reasonable people will differ in the hard cases as to the interpretation of the available evidence. The difficulty is that the courts are not well equipped to handle these technical matters and they would be much better handled by the conservation authority. Kerans J.A. appeared to believe that the Board had this jurisdiction but I have suggested that he was mistaken. ${ }^{212}$

We have also noted one other situation represented by the facts of the Foralta case, in which the Board declined jurisdiction in a pooling matter in a situation where it arguably ought to have assumed jurisdiction. The first modest proposal therefore is to amend the Oil and Gas Conservation Act to permit an application to be made to the Board in a broader range of circumstances than is presently the case. Both the situations referred to here could be handled by permitting a working interest holder to apply to the Board for a ruling on an appropriate allocation principle when the DSU is composed of several tracts under lease to the same entity, or to related entities that are 
not at arm's length and where a third party has an interest in less than all the tracts. Non-participating owners would be given the opportunity to appear as parties before the Board or its examiners and to offer their own interpretation of the data. I should emphasize that this amendment would not be designed to permit an application by "an owner" that did not have a working interest. Rather, it would be designed to provide some protection for a working interest owner in the discharge of its good faith or fiduciary duties to that non-working interest owner.

A corollary to this proposal is that those advising lessors should consider redrafting the pooling clause of the lease so that it is less prescriptive than the standard formulation. This increases the uncertainty for the lessee but, if the above proposal were accepted, lessees would be able to seek the advice of the Board in the difficult cases. This drafting change would have the effect of placing the lessors on the same footing as the holders of non-participating interests following the decision in Mesa.

The second suggestion for reform involves the matter of well licence applications. In the discussion above I supported the Blue Range decision of the Board on the grounds that while the applicant was, as a matter of property law, entitled to drill on the lands because it held an undivided interest throughout the tract, as a matter of policy, a licence should be refused where an applicant's working interest was not the same throughout the DSU because in such a situation there is no available mechanism for sharing production. If this is indeed the stance of the Board, and there are good equity reasons for supporting it, it is perhaps appropriate that the Board amends its well licence application form so as to require the relevant information. The Oil and Gas Conservation Regulations do not provide details as to the form that is to be used. They simply state that the application shall be in the form prescribed by the Board. ${ }^{213}$ The form requires that the applicant indicate whether it "has the right to produce as below." There follow three boxes requiring information as to the formation. Other boxes require information as to whether the rights are in the entire section or part of the section and as to whether the lease is freehold or Crown. An applicant in Blue Range's position could complete this form without disclosing the relevant information that led the Board to deny the application in that case for, as already stated, Blue Range had the right to produce throughout the section and for the relevant formations. My final suggestion therefore is simply that the Board amend its form so as to require the applicant to state whether it has the same interest in all the tracts comprising the DSU. ${ }^{214}$ A negative answer would invite further inquiries from Board staff and perhaps lead to the refusal to grant a licence or the issuance of a licence subject to appropriate terms and conditions. $^{215}$

OGCR, supra note 12, s. 2.010; see also ERCB Guide G-33, Application for a Well Licence: Instructions for Completion of Form DAPI, 2d ed., 1992.

214 Obviously this is a minimalist proposal designed to recognize the sensitivities of the industry to disclosing ownership interests. Another possibility would be to require that the applicant serve notice of the application on all persons that it is aware of that have an interest in the DSU. 